\title{
Nahuas and Spaniards in contact: Cross-cultural transfer as seen through the Nahuatl lexicon
}

\section{Nahuatl and its speakers through the centuries}

Due to a large corpus of written sources, the history of the ancestors of modern Nahuas, the speakers of the Nahuatl language, is one of the best documented as compared with other indigenous groups of the Americas. Given that a significant part of these sources was written in Nahuatl over a long period of time, they provide an excellent opportunity for studying the history of its speakers through their own language and for studying the language itself. A fascinating part of this story involves the prolonged culture and language contact with Spaniards and its short- and long-term consequences in all spheres of life. The history of contact shows how Nahuatl was the tool, the medium, and the catalyzer of cross-cultural transfers, both transforming and being transformed by reality. The 'Nahua world' has always been multiethnic and multilingual. At the time of the conquest, the speakers of its many variants coexisted with speakers of many other indigenous languages in the Mesoamerican 'melting pot', more than 100 of which survive today (the number varies, depending on forms of classification). However, the 'game-changer' in the history of the Nahuatl language and the Nahuas has been the speakers of Spanish themselves, both in the colonial period and at the present time.

\section{Pre-Hispanic history}

Nahuatl forms part of the Uto-Aztecan family of languages, spreading from the southwestern United States to El Salvador and Nicaragua. The core area where it has been spoken in historical and modern times is Mesoamerica, embracing many regions of Mexico and Guatemala. The earliest history of the speakers of Nahuatl is less amply documented. According to the most widely accepted reconstruction, the Uto-Aztecans originated somewhere in the southwestern United States and northwestern Mexico. Controversies surround the subsequent stage of Nahua history. While the traditional view holds that Nahuatl appeared on the Mesoamerican scene only after 700 AD (e.g. Kaufman \& Justeson 2007: 232-323), there are important clues suggesting that it was likely one of the languages 
already spoken in the metropolis of Teotihuacan in the first half of the first millennium AD. Given that Teotihuacan exerted its political control over large portions of Mesoamerica, Nahuatl loans in the Maya glyphic records from the fourth and fifth centuries AD provide tantalizing pieces of evidence pointing to possible connections of this language with the powerful polity. In this period the Central Mexican hegemon exerted strong military, political, and cultural influence on lowland Maya kingdoms and controlled extensive commercial networks (Dakin \& Wichman 2000; Macri \& Looper 2003).

While archeological evidence alone cannot establish the linguistic affiliation of the multi-cultural and multi-ethnic metropolis of Teotihuacan, it does reveal the heterogeneous nature of the city, which had districts inhabited by people coming from Oaxaca and the Maya area. All of this speaks in favor of the hypothesis that speakers of the 'Eastern' branch of Nahuatl were present in Central Mexico at least since $400 \mathrm{AD}$ and then dispersed into La Huasteca, the mountains of Puebla, the Isthmus of Tehuantepec and toward Guatemala, El Salvador, Honduras, and Nicaragua (Dakin 2010: 168). However, scholars disagree on the arrival date and cultural affiliation of representatives of the earlier 'Eastern' branch of Nahuatl. Canger (1988), for example, identifies them, after the demise of Teotihuacan, among the people contributing to the raise of the Toltec state, the main power center in Tula (Hidalgo) in the Epiclassic/Early Postclassic period (ca. 750-1150 AD). Tula's disintegration is usually linked to the arrival of the so-called Chichimecs from northern Mexico, a heterogeneous mixture of groups coming in different waves after ca. 1175-1200 AD. Again, Nahuatl-speaking incomers were most probably among them, resulting in a major dialectical differentiation between the sedentary groups linked to Toltec culture, including possibly descendants of the people of Teotihuacan and the new arrivals. These late incomers are commonly identified as carriers of the so-called Aztec culture, settling throughout the Valley of Mexico and vast areas to the east and south, including Tlaxcala, central Puebla, Morelos, and central Guerrero (Canger 1988: 64-65).

Emerging from this still poorly understood period were numerous polities and small states dominated by Nahua-speaking people. Zones of political centralization in Mesoamerica of that time included prospering towns in the Valley of Mexico, an area offering advantageous subsistence opportunities because of highly productive agricultural areas of intensive cultivation on the southern shores of Lake Tetzcoco. These competing states were called altepetl and each carried a local sense of ethnic identity based on the common mythical-historical origin of the specific group. Their members had rights over certain territories, which could be either their property or tribute areas (Lockhart 1992: 14-25; Berdan 1996, 2006, 2007; Berdan \& Smith 1996, 2003; Smith 2005, 2008). Among these growing centers was Tenochtitlan, the rapidly expanding capital of the Mexica 
altepetl, which by the time the Spaniards arrived in 1519 had become the largest metropolis in the Valley of Mexico. Its role was instrumental in the successful military, economic, and cultural expansion resulting from the creation of the Triple Alliance of Tenochtitlan, Tetzcoco and Tlahcopan, deemed "the Aztec empire" by modern scholars. The central area of the Aztec empire corresponded with the Valley of Mexico and consisted of mainly Nahua-speaking communities. Its conquered lands extended to multi-ethnic and multi-lingual areas in the present Mexican states of Hidalgo, Guerrero, Morelos, Puebla, Oaxaca, and Veracruz.

From the mid-fifteenth century Nahuatl was the main language of the Aztec empire, and its local variants were spoken in numerous regions of Mesoamerica, to the north, south, east, and west of Tenochtitlan, coexisting with other local languages, such as Otomi, Matlatzinca or Popoloca. On the linguistic level, the so-called Central Mexican Nahuatl is characterized by a mixture of Eastern and Western features that are attested in early colonial sources, such as the dictionary of Fray Alonso de Molina (Dakin 2010: 168-169). The roles of Nahuatl embraced socio-political, cultural, and economic functions. Elegant, sophisticated language was used in the elite palaces and royal courts of the Aztec empire, and above all, in Tenochtitlan and Tetzcoco. It was the medium in which songs and poems were composed and performed as well as the language of diplomatic contacts, negotiations, and administration within the empire. Dating back perhaps to the time of Teotihuacan in the first millennium, Nahuatl was also widely used as an interregional language or a sort of lingua franca, especially in the extensive long-distance commercial networks that connected all regions of Mesomerica; hence, Nahuatl attested in Sononusco (Chiapas) and Guatemala in the early colonial period is even sometimes called "pochteca Nahuatl”, from pochtecah, Aztec long-distance merchants (Parodi 2010: 333-334).

\section{Colonial period}

1519 marks the arrival of Spaniards and Spanish, an event that irrevocably changed the destiny of the Nahuas and their language. The native imperial structure and political relationships eventually collapsed after the violent encounter with Hernan Cortés and his army of Tlaxcalans-the unconquered enemies of Tenochtitlan who share their Nahuatl language and much of their cultural traditions with the Mexica-and many formers subjects of the Triple Alliance. The Spaniards managed to take the imperial capital in August 1521 after many months of siege and the heroic defense of its inhabitants. However, the local organization of the Nahua altepetl proved much more resistant to conquest and colonization. Many key elements of the indigenous sociopolitical organization as well as the 
system of beliefs and practices managed to survive, often below the surface of the new political and religious order (Lockhart 1992; Horn 1997).

Under this new system, a single native state, or an altepetl, along with its constituent parts, could become an encomienda (a grant of Indian tribute and labor to an individual Spaniard) and later a Spanish-style municipality (Lockhart 1992: 29). In huge urbanized zones, such as Mexico-Tenochtitlan, an organizational duality was introduced, with parallel indigenous and Spanish municipal structures and organizations. Newly founded centers for European populations, such as the town of Puebla de los Angeles, tended to replicate Spanish patterns more closely despite housing significant portions of the indigenous population. Later on, in the second half of the sixteenth century, Spanish rule established forced congregaciones (congregations or resettlements) of the native people, which continued to be heavily decimated by a series of epidemics caused by diseases brought from the Old World. It is estimated that the indigenous population of Central Mexico (broadly and roughly defined as the area extending from the Isthmus of Tehuantepec in the south to Nueva Galicia in the north) was reduced from ca. 25 million in 1518 to ca. 1.9 million in 1585 and only 0.75 million in 1622 (Borah 1983: 26). According to another estimation, by 1620 diseases of European origin (especially smallpox, measles, and typhus) diminished the original population of this region by about 90 percent (Nutini \& Isaac 2009: 33).

Municipal government based on European models was introduced in the native altepetl, now referred to as repúblicas de indios, in the form of cabildos or town councils; municipalities also served as places of tribute collection and labor organization. With the goal of making local administration capable of fulfilling tribute obligations, the Spaniards often chose to rely on local dynastic rulers. Many native customs and laws continued to be practiced, especially given the fact that community members were performing the function of European-style judges and were in charge of first-instance legal issues. Indigenous people had access to courts of justice at the local level, but could also appeal to a higher instance. It only took a little more than a decade for the Spanish government in New Spain to crystallize at the central level. The viceroy was the voice of the king of Spain, and he was supported by the members of the high court or Real Audiencia located in Mexico-Tenochtitlan. It dealt with criminal, civil, and administrative matters, while religious/church cases usually fell to the ecclesiastical courts. The officers known as corregidores de indios were in charge of larger administrative and jurisdictional units, usually encompassing several altepetl and called corregimientos.

After a few rather incidental attempts during the conquest, Catholic instruction began in 1524, after the arrival of the first twelve Franciscans. Persecutions fell on native communities, and especially the nobility, as the friars gradually became aware of the poor level of response toward their Christianization efforts 
among natives who had received baptism and, supposedly, had been successfully converted to the Catholic faith. Particularly violent inquisitional proceedings were led by the bishop Juan de Zumárraga from 1536 until 1542 when his powers were rebuked. Eventually, the royal order of 1570 removed natives from the jurisdiction of the Holy Office of New Spain, remanding indigenous trespassers against the Catholic faith to episcopal courts and their institutions under the Provisorato de Indios (Greenleaf 1961; Greenleaf 1994: 352; Chuchiak 2012: 8-11). Toward the 1550s, Catholic instruction and the establishment of parish churches started to bear more fruit as a result of the increasing acceptance among the natives of Christian cults and practices. Local communities began to assert ownership of churches, which they considered symbols of local autonomy and often identified with the preconquest temples on whose remains they had commonly been constructed. They sponsored lavish religious festivals and spectacles, not infrequently playing an active role in the selection of a particular monastic order that would be in charge of their parish. Cults of the Virgin Mary and numerous saints gained special popularity as they were perceived as close counterparts of precontact deities and often took over their functions. The native people also began to establish their own religious confraternities modeled on Spanish ones (Burkhart 1989; Lockhart 1992). The gradual acceptance of Christianity, or rather the Christian layer atop the religious 'core' of preconquest origin, is clearly evident in the Nahuatl language recorded throughout the colonial period.

The Spanish colonization was also the source of deep demographic, social, and economic changes in indigenous communities. Epidemics and the resulting depopulation; excessive tribute requirements, forced labor (e.g. in silver mines), and resettlements (congregaciones, reducciones); the disintegration of preconquest long-distance exchange networks the introduction of new crops, domesticated animals, and production modes as well as the gradually increasing pressure on indigenous land-holdings and urbanization were among the key factors of economic and social change. Many Spaniards who settled in New Spain were agricultural entrepreneurs, cattle breeders, and merchants involved in both local and overseas networks. A huge majority of them, however, belonged to the urban, low-middle class, working as shopkeepers, bakers, barbers, muleteers, smiths, tailors, weavers, or cobblers. It is difficult to estimate the growing non-indigenous population in New Spain. Data provided so far (e.g. Borah 1983: 27) should be treated with extreme caution: numbers of Spaniards, including other Europeans and "mixed-bloods of Hispanic culture" was calculated as 57,000 in $1570,114,000$ in 1646 , and 280,000 in 1793 . This is roughly consistent with another reconstruction, estimating the number of Spaniards in all of New Spain directly after the conquest as 2,200, about 7,000 by 1530 and as much as 70,000 by 1600 , including not only peninsulares, arriving from Spain, but also 
locally-born creoles (Nutini \& Isaac 2009: 33). Yet another study proposes the rough number of 60,000 Spaniards for the 1570 s, with some $30 \%$ living in the city of Mexico-Tenochtitlan (Butragueño 2010: 1001). The mestizo group-a general term for persons of mixed Indian-Spanish heritage-had increased considerably by 1600 . Some of its members served in important positions, both private (e.g., stewards for Spanish encomenderos or farmers) and public, such as municipal offices (Nuttini \& Isaac 2009: 45-48). Perhaps more important than the actual numbers of non-indigenous members of the general population was the social prestige they enjoyed as well as the administrative, cultural, political, and economic roles they performed. The numbers and resources of the Spanish, creole, and mestizo sectors of the population continued to grow steadily toward the end of the colonial period, deeply changing the demographic, linguistic, economic, and socio-political landscape of New Spain.

Some of the economic initiatives originally undertaken by Spaniards and mestizos were gradually adopted by members of the indigenous society. Thus, Nahua nobles and members of the middle class engaged in animal husbandry (cattle, sheep, and horses), the establishment of factories for textile production (obrajes), as well as enterprises for sugar and salt production, mining, and the wood trade, successfully implementing and following European modes of production and economic activities. These innovations are amply reflected in the adoption of relevant terminology in Nahuatl, reflected in indigenous documents. At the same time, the traditional economy continued to provide basic income and sustenance for native nobles and commoners throughout the colonial period. Rulers and nobles not only supervised tax collection for the Spanish Crown, but also received tribute and labor from their subjects as well as crops from the dependent laborers who worked their lands. However, as the colonial period progressed, non-indigenous residents (Spaniards, creoles, mestizos and people of African origin) began to establish themselves more and more in native towns. Although still representing a minority, they began to wield considerable economic influence and displace traditional indigenous authorities.

\section{Nahua colonial writing and uses of the language}

A particularly important part of Nahua colonial history was the use of alphabetic writing based on Spanish orthography. The general convention was most probably developed by mendicant friars along with their indigenous collaborators, in all likelihood between 1525 and 1530. It became further refined in the 1530s and 1540s, when it was also adopted by the incipient group of indigenous scribes and notaries. This usage of Nahuatl in alphabetic writing was facilitated by a 
well-established preconquest tradition of books and glyphic records. Orthographic conventions-never unified through the colonial era-were based on the Spanish values of the Roman alphabet that represented similar sounds to those in Nahuatl. Even though Spanish had close equivalents for the majority of phonetic values in the native tongue, several features of Nahuatl posed certain challenges. This was the case of the glottal stop, glottal fricatives, and vowel length, all of which were usually left unmarked in writing. Several consonants that were voiced in a prevocalic position, suffered spelling changes in the new orthographic system when they became devoiced in a syllable-final position: $h u-[\mathrm{w}]>-u h[\mathrm{M}] ; c u-\left[\mathrm{k}^{\mathrm{w}}\right]>$ $-c u h /-u c\left[\mathrm{k}^{\mu}\right] ; y-[\mathrm{j}]>-x\left[\int\right]$. Other non-compatible elements presented less difficulties: [tt] and [ts] were rendered as the digraphs $\langle t l\rangle$ and $\langle t z\rangle$, while $l l$, representing [j] in Spanish, was used according to the Latin model to render the Nahuatl [11]. This system was adopted and transformed in multiple ways by indigenous scribes and authors who continued training their successors until the end of the colonial period (cf. Melton-Villanueva 2016). Nahua writing remained far from becoming standardized given that writers' important concern was to render the oral characteristics of speech. This included word-initial or word-final phonetic features that could be transformed as a result of interaction with the sounds of neighboring words. This was further complicated by the fact that the Nahuas tended to register the sequence of sounds in phonological phrases rather than focus on words as separate and self-standing entities (Lockhart 1992: 336-339). From the late seventeenth and through the eighteenth centuries Nahuatl orthography became even more regionalized in its representation of local spelling variants (Lockhart 1991: 122-134; Pizzigoni 2007: 35-39).

Nahua communities and especially municipal organizations became important spaces for the use of alphabetic writing, responding to more mundane needs than religious and educational textual productions. In Tlaxcala the presence of a well-trained municipal scribe is documented as early as in 1543 (Olko \& Brylak 2018) and large indigenous municipalities such as Mexico-Tenochtitlan were probably not far behind. By the third quarter of the sixteenth century most of the altepetl had their own notaries working for the municipal government, while larger, populous towns could afford more than one functionary of that kind. They were all kept quite busy producing textual records both for cabildo authorities and individual petitioners, testators, and litigants. The extensive corpus of Nahuatl texts, unparalleled on the American continents-even taking into account the textual records produced by other advanced Mesoamerican cultures, such as the Maya, Mixtecs or Zapotecs-attests to the vitality of indigenous culture during the colonial period. This body of documents embraces historical annals, traditional speech, theatrical plays, petitions, letters, legal proceedings, assertions of local traditions and rights called "titles," religious and devotional texts (among 
them translations and reinterpretations of European sources), and a large mass of legal and economic texts, including wills, bills of sale, parish records, censuses, and other demographic records.

The written corpus of Nahuatl texts shows that colonial 'central Nahuatl' was by no means a single, homogenous variant of the language: differences are clearly seen not only between the Valley of Mexico and other regions such as Puebla or Tlaxcala, but also between localities in the Valley itself. Many sources from the northern periphery also reflect local variants of Nahuatl, with consistent non-central varietal features (e.g. Sullivan 2007). Some of the northern communities indeed used Nahuatl as a second language; there were many, however, that probably spoke local variants present long before the Spanish conquest. This is implied in an account written by Fray Antonio de Ciudad Real ([1872] 1976) who between 1584 and 1589 accompanied the inspector of Franciscan provinces Fray Alonso Ponce in his trip extending from Zacatecas in the north to Nicaragua in the south. He explicitly confirmed a very wide presence of Nahuatl across geographically distant regions: “This Mexican language runs through all of New Spain. Hence, anyone who knows Nahuatl can go from Zacatecas, and even much further beyond, to the extreme border of Nicaragua, more than six hundred leagues in all, and through all of this area, he can be assured of finding someone who understands him. There is no small village, at least along the Royal Highway, where there is not a Mexican Indian or one who understands Nahuatl” (Ciudad Real [1872] 1976, v. I: 75; transl. after Heath 1972: 24). ${ }^{1}$ The uses of Nahuatl in colonial New Spain were thus not limited to members of Nahua communities. Persons of noble status belonging to other ethnic groups as well as numerous non-elite individuals of different backgrounds, including Spaniards, used spoken and written Nahuatl to facilitate communication in different aspects of colonial life (Yannanakis 2012: 669-670).

The need to learn and practice Nahuatl by the Spanish-speaking inhabitants of New Spain is confirmed by the publication in 1610 of the Vocabulario manual de las lenguas castellana y mexicana by Fray Pedro de Arenas, a practically oriented dictionary intended to help with a daily communication. While this work was an especially useful resource for people communicating in Nahuatl for commercial and administrative purposes, a large number of mestizos and creoles learned the

1 "y esta [lengua] mexicana corre por toda la nueva españa, que el que la sabe puede ir desde Zacatecas y desde mucho más adelante hasta el cabo de nicaragua, que son más de seiscientas leguas, y en todas ellas hallar quien le entienda, porque no hay pueblo ninguno (al menos en el camino real o pasajero) donde no haya o indios mexicanos o quien sepa aquella lengua, que cierto es cosa grande". 
language due to quotidian and continuous contact with speakers in their workplaces, in their homes and in households employing indigenous servants and workers (Parodi 2010: 334). The Nahuatl language also became a fundamental tool for providing native audiences with Catholic religious concepts such as terms for God, heaven, hell, devil, demons, soul, redemption, sin, confession, sacrifice, and offerings. Some of these words were in fact preconquest terms, either sightly modified or with extended meanings. On a general level, it is certainly true that from the sixteenth century on, different kinds of polyglossia existed in New Spain, some brought from Spain-between Latin, high Spanish and low Spanish-and some originating in the indigenous world and further developed in the colonial period. Thus, Latin and Spanish were high varieties in New Spain, while Nahuatl occupied a higher position with respect to other indigenous languages (Parodi 2010: 308-310).

\section{Language policy, Nahuatl-Spanish contact and multi/ bilingualism in the colonial period}

In terms of the language policy of the Spanish Crown, Nahuatl held a special position among indigenous tongues in New Spain. However, its formal recognition was not immediate. In 1550, King Charles I of Spain, expressing his doubt that any local tongue could be fully capable of conveying Christian doctrine, issued an order that all indigenous subjects of the Spanish crown be provided by ecclesiastics with the means to learn the Castilian language. The friars and other ecclesiastics opposed the royal decree, proposing to use Nahuatl as the language of general instruction (Phelan 1970: 87-89; Parodi 2010: 331). However, in 1570 king Philip II, convinced by the friars that linguistic diversity was a too big of a challenge to handle, he raised Nahuatl to the status of the official language of the indigenous people in general (Heath 1972: 25-26). His royal decree gave the language an exceptional position among other native tongues, while the ecclesiastics became, officially at least, obliged to learn it. This situation was reinforced in 1574 when the king further declared that members of the clergy should not be admitted to parishes without knowledge of "the general language of the Indians," that is, Nahuatl (Recopilación de Leyes, lib. I, tit. VI, ley 30, 1574, 1578). Furthermore, in order to provide institutional and practical support for teaching Nahuatl to the clerics, Philip II ordered the University of Mexico to establish a chair of Nahuatl (Heath 1972: 27). General pressure toward Hispanization increased in the following centuries. The most serious attempt to radicalize this change state policy came on October 6, 1769 when cardinal Francisco Lorenzana, the archbishop of Mexico issued his famous pastoral letter concerning the tongues of New Spain. 
He stated in it that different native tongues are like "a contagious disease that removes the Indians from social intercourse with Spaniards. It is a plague that perverts the dogmas of our Holy Faith” (Lorenzana 1770; after Heath 1972: 212). King Charles III, following the arguments of Lorenzana, signed the Real Cédula of April 16, 1770, a royal decree that launched the formal policy of monolingualism, imposing Spanish as the only legal language of the Spanish crown. Nonetheless, the implementation of this policy seems to have been rather modest. It is estimated that through the three centuries of Spanish rule only some $20 \%$ of the indigenous population actually acquired the language of the colonizers (Pellicer 2010: 653). Language skills in Spanish were usually developed through social and economic interactions in urbanized contexts rather than through institutional instruction. And due to the relatively favorable language policy in effect during most of the colonial period, Nahuatl remained the most widely spoken, and often also dominant, local and regional language in many, already multilingual parts of New Spain. Moreover, it also gained new functions and spaces of use.

In the first decades of contact, even before the initial favorable trends in the official language policy were set in motion, Nahuatl gained a key place in colonial educational spheres. Schools and colleges integrated the language into their educational spaces and curricula, greatly helping and encouraging native elites and intellectuals to engage in dialogues with European culture, thought, and science. Indigenous intellectuals often served as bridges between new spheres of knowledge-including linguistic innovations such as loanwords from Spanishand their peers. Since students of such schools were usually bi- or trilingual, they thus became important source of language change, along with translators and notaries in indigenous communities. This aspect of cultural impact was also facilitated by the fact that the first schools also served as venues for experiments, conducted by friars and their indigenous collaborators, in creating Nahua Christian vocabulary. Some of these elements of language planning entered daily use through Catholic instruction with the application of doctrinal materials created as a result of such enterprises. The products of specific experiments in translation significantly preceded developments resulting from contact-induced change attested in indigenous mundane and legal sources (Granicka 2018).

The extensive multilingualism in local languages that unquestionably existed in the early and middle colonial period, began to gradually disappear in the eighteenth century, and this process accelerated during the nineteenth and twentieth centuries. However, the scale of Nahuatl-Spanish bilingualism-as well as its possible geographical scope-is a much more contentious issue. The combined evidence from Spanish and indigenous sources points to what could have been, in the first phase of the colonial period, a partial and elitist bilingualism represented by native nobles and Spanish friars and clerics, accompanied by an 
incipient and growing general bilingualism among the indigenous population in specific regions and higher social groups in the second part of the colonial period (Zimmermann 2010: 945, Tab. 15). More debatable are other phenomena proposed for the colonial period (cf. Zimmermann 2010: 945), such as a significant decrease in native monolinguals, a decreasing proficiency in and usage of indigenous languages, or an increase of indigenous monolinguals in Spanish. Available evidence suggests that the presence and scope of such trends greatly depended on the kinds of settings and regions. It is much more probable they were largely restricted to urban contexts, where bilingualism was not stable and led to Spanish monolingualism after several generations. This scenario seems to be supported by the decreasing number of documents in Nahuatl in the late seventeenth and eighteenth centuries in such cities as Mexico-Tenochtitlan and Toluca, where indigenous legal matters were increasingly conducted in Spanish.

The most intensive language and culture contact took place in large towns. The impact of the non-native population was strongest in, but not limited to, this context. On certain levels, the geographical and legal division of 'mixed' towns into Spanish and indigenous municipalities not only created a jurisdictional and administrative separation between these ethnic groups, but also reinforced the situation of polyglossia (Borah 1983: 32-33; Parodi 2010: 313, 332). In other words, the administrative divisions did not prevent culture and language contact: daily interactions between natives and Spaniards must have contributed to the development of different levels of bi/multilingualism, even if transitional and unstable. Interesting pieces of evidence on inter-ethnic relationships come from Mexico-Tenochtitlan. By 1612 there reportedly lived about 80,000 indigenous persons, some 50,000 blacks and mulattos (mainly of African and indigenous origin) and about 15,000 "Spaniards" (including creoles) in this city. This means, if these figures are credible, that the city's population was ca. 35\% black/mulatto and ca. 10\% "Spanish” (Nutini \& Isaac 2009: 34).

An interesting picture of multiethnic social life seen through indigenous lenses emerges from the testimonies of the native chronicler Don Domingo Francisco de San Antón Muñón Chimalpahin Quauhtlehuanitzin. He was born in 1579 in Amecamecan Chalco, an altepetl located the southern part of the Valley of Mexico, but lived since 1593 in Xoloco, an indigenous neighborhood of the metropolis where he came to work as a fiscal (an assistant and steward) at the church San Antonio Abad (Schroeder 2012: 64). In his annals Chimalpahin describes in detail the colorful life of the multi-ethnic metropolis. For example, he points to commercial activities as a space of close interaction between different groups. His account sheds light on the entrepreneurial activities carried out by indigenous elites in the colonial reality and also calls attention to the lack of racial or status-related separation in daily activities. Chimalpahin was no doubt 
one of a number of indigenous culture-brokers acting in many ways as a mediator between the two worlds, as is clearly reflected in his writings. A huge amount of loanwords contained in the present dictionary come from his annals where he described in detail the colonial reality of Mexico-Tenochtitlan. It is debatable how much of the new, contact-induced lexicon penetrated into the daily language of the Nahua people, especially those living outside the capital. It is significant that the data presented in the dictionary show that only a small percentage of loanwords used by Chimalpahin are also attested in the mundane sources coming from different Nahua towns.

The situation in native towns and especially rural communities was quite different from the metropolis. On the one hand, many of them were characterized by very limited bilingualism and pervasive monolingualism in heritage tongues. This situation remained until the second half of the twentieth century, and in the most secluded, peripheral locations - to much more recently. On the other hand, the presence of Spanish speakers in indigenous towns and their commercial transactions with respect to native land are very well attested in the corpus of Nahuatl documents from Tlaxcala, whose native protagonists entered into economic and legal relationships with Spaniards. Quite naturally, in those native spaces individual bilingual speakers gradually appeared. They included notaries, selected municipal officials, perhaps also some of the collaborators of friars and merchants capable of negotiating with external agents and participating in complex power relationships. They acted as innovators in the early experiments with the creation of neologisms, the adoption of loanwords, the coinage of syntactic calques, and other phenomena of contact-induced language change. Such innovations, as already pointed out, although attested in textual records, do not necessarily reflect the language spoken by the wider population. While the groups of indigenous 'intermediaries' should be considered an important source of linguistic innovations in their circles, this kind of bilingualism, perhaps with the exception of large urban contexts in the middle and late colonial period, was not, in my opinion, widespread and generalized in indigenous populations. There is no evidence of balanced indigenous-Spanish bilingualism going beyond individual bilingualism. Bilingualism in urban contexts was probably quite unstable. By 'unstable bilingualism' I am referring to a situation of acquisition and use of both the heritage language and Spanish not exceeding several generations and leading, eventually, to abandonment of the mother tongue. It seems significant that even in Tlaxcala, despite a well attested and steadily growing presence of Spaniards from the sixteenth century on, Nahuatl managed to survive up until the 1960s-1970s, including a significant degree of monolingualism in this language, especially in the communities on the slopes of the Malinche volcano. Nahuatl-Spanish bilingualism, however, quickly expanded in the second half 
of this century, leading to an accelerated shift to the national language within a maximum time span of two to three generations. This contradicts opinions stating that modern Tlaxcalan Nahuatl can be described as "intense and relatively stable bilingualism characteristic of the region" and that "opposition [between Nahuatl and Spanish] is suppressed or eliminated by their simultaneous usage side by side" (Field 2002: 126).

\section{Nahuatl after independence}

The history of indigenous communities and their languages, including Nahuatl, was profoundly affected by the changes brought about after 1821 by Mexican independence. At the onset of the Mexican republic the category of indios was abolished, along with the rights, privileges and some important administrative and organizational principles it conferred at the community level. The general and enduring strategy of the state oscillated between extermination and assimilation. One of its most salient goals was to integrate indigenous people into the global labor market, hispanizing and modernizing them. Their remote ancestors became an idealized and mythical image of the past, which created a huge distance between the 'historical Indian', whose noble past deserved to be recalled and glorified, and the poor, modern Indian belonging to the most strongly marginalized sector of society (Villavicencio Zarza 2013: 81-82).

As a result of emerging policy, the percentage of speakers of indigenous tongues dropped significantly within the first 50 years of the nineteenth century. From an estimated $37 \%$ of the entire population in the middle of the century, the number dropped to some $17 \%$ or a total of $12,632,427$ speakers of native language in the first modern census carried out in 1895 (Villavicencio Zarza 2013: 48-49). All of these numbers must be treated with extreme caution and taken, at best, as huge approximations. Undoubtedly, the official results of the first national census convey an image of a linguistically and culturally homogenous country, but they were likely influenced by the form of the questions and the methods and language of their administration. Another factor could have been an expected or enforced identity choice that obscured a probably much higher number of speakers of indigenous languages who were either registered as mestizo citizens or preferred to pass as such, a tendency that greatly expanded in the next century.

Notwithstanding the difficulties associated with reliable assessments of actual numbers of speakers, there is no doubt that these continued dropping sharply. The language policies developed and implemented by the liberals throughout the nineteenth century provided strong grounds for this situation. Spanish became absolutely dominant in the political and administrative spheres, 
displacing indigenous languages and confining them to private zones. As a result, the communities using indigenous languages became secluded hamlets whose marginalized speakers knew little Spanish. People who left their communities and incorporated themselves into the external labor market, had little choice but to shift to Spanish (Villavicencio Zarza 2013: 56). Gradually, Spanish began to gain more and more presence, not only in communicative interaction between indigenous and non-indigenous people, but also in different social spaces of daily life in native communities, thus contributing to the growth of unstable bilingualism and the shift to the dominant language (Villavicencio Zarza 2010: 723-730; González Luna 2012: 92-93). This policy has resulted in the accelerated, massive assimilation of native communities, including the Nahuas, and the rapid adoption of Spanish at the expense of the heritage language, especially in the second half of the twentieth century.

\section{Nahuatl today}

Despite the long-term pressures of assimilation into the national society, the descendants of the Nahuas survive today in numerous communities in a number of Mexican states, including Estado de Mexico, Guerrero, Hidalgo, Morelos, Oaxaca, Puebla, San Luis Potosi, Tlaxcala, and Veracruz. Many of them continue to speak their language, but its active use is much more common in rural rather than in urbanized areas. There are several major classifications of the dialectology of surviving modern variants of Nahuatl. According to Canger (1988) a fundamental distinction exists between central and peripheral Nahuatl. Central groups embrace variants that are spoken in the Valley of Mexico, northern and central Puebla, Morelos, and Tlaxcala. In this classification Huastecan and Central Guerrero Nahuatl are included as 'Central dialects,' but described as sharing certain traits with neighboring peripheral variants. The latter embrace the Western Periphery, Northern Guerrero, Sierra de Puebla, Isthmus, and Pipil (Canger 1988: 45-59). A different proposal was developed by Lastra (1986) who, as a result of the analysis and comparison of a number of phonological, morphological and lexical traits, distinguishes four areas: Center, La Huasteca, Western Periphery, and Eastern Periphery. More recently (Lastra 2010: 856), she differentiated three main areas and a number of subareas: Western Periphery (West Coast, western part of the state of Mexico, Durango-Nayarit), Eastern Periphery (Sierra de Puebla, Isthmus, Huasteca), and Center (nuclear zone; Puebla-Tlaxcala; Xochiltepec-Huatlatlauca, south-east of Puebla, central Guerrero, southern Guerrero). These regions differ significantly in terms of language endangerment and their specific sociolinguistic situation. While in some of them 
Nahua-speaking communities still form more or less homogenous areas, in most cases they have been reduced to isolated 'islands' separated by entirely Spanishspeaking zones.

The Mexican National Institute of Statistics and Geography (INEGI) reported in 2010 an official population of as many as 1,544,968 native speakers of Nahuatl. Nonetheless, in the overwhelming majority of those communities that have been able to carry their language into the second half of the twentieth century, intergenerational language transmission has been drastically weakened or has broken down entirely over the last few decades. For example the number of monolingual speakers of Nahuatl was reported as $10,3 \%$ in the census of 2010 , but fell to $7 \%$ in 2015 (INEGI, consulted 02.04.18). With few exceptions, it is only in the most secluded peripheral communities that Nahuatl is still transmitted to children at home. Dwindling language transmission and the expansion of Spanish is accompanied by the shrinkage of spaces of use and the lack of educational spaces in Nahuatl. Many forms of racism as well as economic pressures resulting in massive migration to large Mexican cities and the US have also had a very negative impact on language maintenance.

Migration to Mexican cities and the US has been increasing in Nahua communities since the 1980s and the 1990s, though of course with diverse levels of intensity in different communities and regions. Speakers of Nahuatl were reported in high numbers for Mexico City (over 37,000) and the cities of Puebla (over 30,000), Acapulco (ca. 3800), Monterrey (over 3000), San Luís Potosi (ca. 2000), and Guadalajara (ca. 1500); they share very high degrees of bilingualism (Butragueño 2010: 1030-1034). Immigrants commonly abandon their mother tongue as they attempt to pass for 'mestizos' in order to avoid ethnic discrimination, which is considerable in urban contexts. The greatest abuse is found with regard to native children in school. It is heaviest in primary school, less at the secondary level, and then intermittently in universities and technical schools (Nutini \& Isaac 2009: 64). In urban zones many speakers decide to limit the use of their native language to private spaces (Martínez Casas 2010: 1409-1444).

As already mentioned, 'original' Nahua communities differ significantly in terms of their sociolinguistic situation. In some of them, such as those of Chicontepec and Sierra de Zongolica in Veracruz, Sierra Norte de Puebla, and certain parts of Guerrero, transmission and maintenance in the youngest generation largely persisted until the end of the past century and has only been more seriously threatened in the last two decades. Such communities and regions, located in isolated mountainous or tropical regions, were deemed 'regions of refuge' (Aguirre Beltrán 1967). Natural conditions protected their inhabitants from forced 'modernization', allowing for the continuity of language, culture, social structures, and identities. In other regions, such as central Puebla, Tlaxcala and Valley 
of Mexico, these kinds of changes were already occurring several decades ago. As a result, usually only a small percentage of the members of the oldest generations has an active knowledge of Nahuatl. The modern lexical material included in the present dictionary was mainly collected in three very different regions where Nahuatl is still spoken: in more traditional rural regions of Chicontepec in Veracruz and Xilitla in San Luis Potosi as well as in the much more urbanized area of Tlaxcala.

Chicontepec rural communities, located in a hot and humid geographical setting, retain many features of the traditional economy (based on corn agriculture). Due to a limited (until recently) road system and relative isolation, communication with the outside world has been fairly restricted. The Nahuas of Chicontepec share the strong identity of macehualmeh, or indigenous people, and they employ this term to differentiate themselves from outsiders or coyomeh (lit. 'coyotes') (Sandstrom 1991: 68-69). Community members continue to participate in a number of traditional religious ceremonies linked to the life cycle of corn, revered as the deity Chicomexochitl as well as other important feasts, such as the Day of the Dead, called xantolon. The language is still widely spoken, although the shift to Spanish and the lack of language proficiency among the youngest generations is progressing. In the municipality of Chicontepec, out of the total population of 52,702 persons, 37,000 inhabitants (ca. 70\%) declared themselves to be speakers of indigenous languages, mainly Nahuatl (INEGI 2010); the clear majority was bilingual, as only 3,051 (mainly the eldest generation) did not speak Spanish. Proportions are different with the youngest age groups, revealing the weakening intergenerational transmission and shrinking use of Nahuatl. of the total of 12,708 children between three and fourteen years of age, only 6,499 (ca. 51\%) were reported in 2010 as speaking an indigenous language, and of these, only $86(0,68 \%)$ did not speak Spanish.

Much of our ethnolinguistic material used in the dictionary comes from the rural town of Tepoxteco whose population amounts to over 400 inhabitants. Intergenerational language transmission has been maintained in a large number of families, although some families switched to Spanish. There is an increasing pattern of transmission between grandparents and grandchildren, with the generation of parents tending to speak Spanish. Socialization in Nahuatl has been quite strong, at least until recently, because even some children of Spanishspeaking families were able to acquire active competence in the heritage language. All persons up to approximately 50 years of age are bilingual in Nahuatl and Spanish. Some members of the oldest generation are largely monolingual in Nahuatl or possess a limited competence in Spanish. Children, however, are increasingly exposed to Spanish throughout their entire education. The idea that Nahuatl is of little use is prevalent, especially among the younger generations. 
The are currently several bilingual preschools and primary schools in the region where Nahuatl is present as a 'course' (materia) introduced after the recent changes in the indigenous educational system. This class is usually held as an informal conversation in the heritage language, while all formal teaching is carried out in Spanish.

The sociolinguistic situation of the much more urbanized Tlaxcalan communities is very different. These communities are located on the western and southwestern slopes and plains surrounding the Malintzin volcano, east of the Puebla-Tlaxcala highway. This area has long been considered as a "particularly indigenous cultural island within the Spanish-speaking communities of Tlaxcala and Puebla", characterized by systems of mayordomías (sponsorship of the worship of holy images), the ayuntamiento religioso (an organization of lay functionaries of the community's Catholic church), and the complex system of ritual kinship known as compadrazgo (Hill and Hill 1986: 7). A huge part of the community continues to live in extended-family households, but traditional agriculture persists only in order to complement family earnings derived primarily from wage labor, local industries (such as textile production) and other small businesses. Local organization still preserves features of Nahua corporate government, characterized by an ingrained system of cargos (offices) and communal cooperation. Massive migration to the United State has had a strong impact on local social structure and economic life. It has reached a tremendous scale in some of the communities, such as San Francisco Tetlanohcan, where a large number of families are permanently split between Mexico and the United States, with only the oldest generations remaining in Tlaxcala.

Due to forced Hispanization within the school system as well as the discrimination and economic disadvantages associated with the indio class, the shift from Nahuatl to Spanish accelerated in the second half of the past century and intergenerational transmission has been almost entirely broken. There are many passive speakers in the younger generations. Exceptions to this pattern are two neighboring communities on the western slope of the volcano Malintzin: San Miguel Canoa (administratively belonging to the state of Puebla) and San Isidro de Buensuceso (part of the municipality of San Pablo del Monte, Tlaxcala). The majority of community members in these two towns still retain some level of proficiency in Nahuatl. According to the estimations by Nutini and Isaac (1974) around 1890 in over 100 communities along this western slope of the Malintzin more than $70 \%$ of the population was monolingual in Nahuatl. One hundred years later, in the 1990 census (INEGI 1990) only San Isidro had a level of monolingualism surpassing 10\%. And in the 2010 census, of the 10,000 speakers of Nahuatl recorded in the entire municipality of Pablo del Monte, only a little over 200 were monolingualroughly $2 \%$-in the heritage language, including 11 children up to the age of 9 
(INEGI 2010). These trends notwithstanding, San Isidro Buensuceso constitutes an exception in the maintenance of the heritage language in the Malintzin region because young people and children continue to achieve certain levels of proficiency in Nahuatl. It is significant that today language transfer takes place mainly in families that cultivate the land or work in the hills/forest (montaña) and do not participate in the social networks where the usage of Spanish is required on a regular basis. Even so, Spanish is much more common among young people, who share the widespread association of Nahuatl with older people and peasants (Nava Nava 2016).

The situation in the Tlaxcalan municipality of Contla de San Juan Cuamatzin, where most of our research for this region was carried out, represents a much more advanced stage of language shift. According to the last census (INEGI 2010), out of the entire population of 33,109, only 5,124 (ca. 15,5\%) identified themselves as speakers of Nahuatl, and only fourteen were determined to be monolingual. Although some of the elderly speakers did not learn Spanish until they were in their forties or fifties, today there are no monolingual Nahuatl speakers left. Very few children and teenagers are able to speak the language. Of the 8,477 children between three and fourteen years of age, only 250 (ca. 2,9\%) were reported to be speakers of Nahuatl. Many children and teenagers from this region who understand Nahuatl learned it from grandparents rather than parents. Extensive, unmarked code mixing is the norm, and communication is usually carried out in Spanish, even among those who have some level of competence in Nahuatl. The accelerating loss of the heritage language as well as massive lexical substitution and mixing with Spanish are reflected in the dictionary entries based on the recent recordings of speakers from Contla.

\section{Language and culture contact as reflected in the Nahuatl lexicon}

This dictionary of Spanish loanwords in Nahuatl derives from an extensive database of language contact phenomena identified in over 340 colonial texts $\left(\right.$ clas $1250^{2}$ ), a monolingual dictionary of Modern Huastecan Nahuatl (Sullivan et al.2016) and ca. twenty hours of modern recordings of several varieties of Nahuatl (Veracruz, east2538 NHE; Tlaxcala, Puebla, cent2132 NHN). The comprehensive

2 Glottocode. See (Hammarström et al. 2016) http://glottolog.org/. Where possible, three-letter ISO codes are also provided. 
analysis of both older sources and modern print and linguistic materials, allowing for a reconstruction of larger trends over time, is a major innovation in the study of this field. The database contains 57,731 attestations, including 18,233 loanwords and 925 loanblends. Best represented among the colonial texts is Central Mexican Nahuatl in several of its regional varieties, including documents from the Valley of Mexico, Tlaxcala, Puebla, Toluca Valley); however, there is also material included from the southern (Soconusco, Guatemala) and northern (Jalisco, Zacatecas) peripheries. The database includes all major genres of colonial writing in Nahuatl, including literary and encyclopedic works, colonial dictionaries, annals, and mundane documents. The analyzed corpus embraces both single documents and larger works such as colonial dictionaries, ecclesiastical sources and extensive works such as the Florentine Codex and the Primeros Memoriales compiled by Fray Bernardino de Sahagún and his native collaborators. Ecclesiastical words and dictionaries have made it possible to look into the processes of translation and creation of new lexical resources, including the results of linguistic experiments with Nahuatl semantic fields, morphology, and syntax.

Mundane documents in turn have proven invaluable for studying both formulaic and quotidian language use and the extent of adoption of contact terminology attested in colonial dictionaries by actual speakers of Nahuatl and notaries working in native communities. Many of them are legal documents that often include testimonies presented by witnesses coming from specific localities, which makes it possible to identify essential differences in language use and in observing changes over time. They also reveal the gradual introduction of Hispanized lexicon and structures by bilingual notaries, often acting as agents of language change. This repertory of sources has been complemented with historical annals, religious plays, petitions and economic documents. Overall, the examination of the large body of material amassed in the database makes it possible to hypothesize about the extent and trajectory of contact-induced innovations in relation to particular linguistic features of Nahuatl (Olko \& Sullivan 2014; Olko 2015, 2018; Olko, Borges \& Sullivan 2018). The database is also a very rich source for the reconstruction of the process of lexical borrowing in different genres of Nahuatl writing and through them, in different spheres of life. Moreover, it provides insights into this process in modern Nahuatl, five centuries after the initial contact with Spanish, revealing both similarities and essential differences with regard to the trends registered in the colonial period.

Borrowing as understood here refers to changes in the inventory of a recipient language as a result of contact with a donor language (Matras 2009: 155; Andrason 2020). Matras and Sakel introduced the differentiation between matter (MAT) and pattern (PAT) borrowing in contact situations. MAT-borrowing occurs 
when "morphological material and its phonological shape from one language is replicated in another language” (Sakel 2007: 15; Matras \& Sakel 2007), involving all lexical classes: nouns, verbs, adjectives, adverbs, adpositions, conjunctions, complementizers, interjections, and particles. PAT refers to the replication in the recipient language of "the organization, distribution, and mapping of grammatical or semantic meaning, while the form itself is not borrowed" (Sakel 2007: 15). Both the dictionary and the present study focus on matter borrowing, although the examples from colonial and modern sources also reveal phenomena of the borrowing of grammatical patterns. The main types of lexical phenomena recorded in the database include native creations (neologisms), borrowings, meaning change, and different categories of calques. Loan matter from a source language can take the form of morphemes and more complex structures, such as words and phrases. However, these complex structures enter the recipient language as unanalyzable units: as words (i.e. lexemes), not lexical phrases; in other words, they loose their internal structure (Haspelmath 2009: 37). Therefore, although single loanwords from Spanish form the core content of the dictionary, loan phrases are also included. The latter type of borrowings were typical of the early phase of contact when bilingualism with Spanish was absent or very limited. These include expressions, such as the following, whose Nahuatl meaning or meanings given here may be different from their original ones in Spanish: a la huerta 'the garden', 'at the garden', 'to the orchard' meaning 'garden', Espiritu Santo 'the Holy Spirit', alcalde mayor 'chief magistrate', Audiencia Real 'high court of New Spain', Viernes Santo 'Holy Friday', víspera 'vespers', 'eve' or 'evening', cadena de oro 'golden chain', or a la China 'China', 'from China', 'in China', 'in the Philippenes', 'to the Philippenes', 'in the Orient'.

Loanwords often undergo phonological, semantic, and morphological adaptations, which are described in more detail below. Their role and function in speech will differ depending on a number of factors, such as the degree of bilingualism or language proficiency in the source and target languages in contact, and patterns of use. More 'overt' borrowing strategies with minimal adaptations are considered more typical of generalized bilingualism, while more 'covert' and profoundly adapted borrowing is more common for limited or absent bilingualism (Matras 2007: 40). Moreover, adaptations of borrowed lexical material in the recipient language are contrasted with 'nonce' borrowings and code switching, where adaptations are usually lacking (see below). In fact, precise differentiation between borrowing and code-switching may often be problematic or impossible (Matras 2009; Myers-Scotton 2002) and this is also the case for our modern sample. Important criteria include regularity of use and structural integration (Matras 2009: 106), but this is often difficult to determine without extensive data. Obviously, the role and motivation for borrowing as well as patterns of code-switching 
in our material varies between historical epochs. It is intra-sentential codemixing, often differentiated from inter-sentential code-switching, that is usually difficult or impossible to differentiate from borrowing in the modern material used in the dictionary. These contemporary data come from contexts characterized by widespread Nahuatl-Spanish bilingualism and show no signs of phonetic or morphological adaptations. However, thanks to our methods of data collection and analysis, the dictionary makes it possible to look at the trajectory, continuity and degrees of adaptation of use of specific loanwords across different time periods, regions and documentary genres. It also enables us to trace the longevity of neologisms and to understand better the mechanism and timing of their replacement by loanwords (see below). For example, tlapohualtepoztli (tlapohual-tepoz-tli, a_count-copper/iron-ABS.SG, 'copper/iron for counting'), used for a 'striking clock', first appeared in the municipal records of Tlaxcala as early as 1550 (March 3, 1550, Tlaxcallan City Council Meeting in Lockhart, Berdan \& Anderson 1986: 70), and was still attested in the same province toward the end of the seventeenth century in the annals of Zapata y Mendoza (1995: 160). However, the first attestation of the Spanish word for clock, reloj, which is used in Nahuatl variants today (Sullivan et al. 2016: 412), appears in a set of Tlaxcalan annals compiled during the second half of the seventeenth century, although it is based on earlier records (Townsend ed. 2010: 164-166).

In addition, borrowed Spanish lexicon sometimes reveals shifts in meaning that transcend semantic fields in the source language. For example, escritura 'writing, scripture' was employed around 1580 in Colhuacan for a 'writing desk' (in Cline \& León-Portilla 1984: 4; f. 35r). In turn, enemigo was not originally adopted with the basic meaning of 'enemy' (a word with this meaning was already present in Nahuatl), but appears in 1683 in the annals from Puebla in a narrower sense as 'Englishman', referring specifically to the English pirates who attacked Veracruz (in Townsend 2010: 124, 126, 134). Yet another case is that of árbol 'a wooden frame or pole for fireworks', referring, by extension, to the fireworks themselves (e.g. Zapata y Mendoza 1995: 320, 538).

A separate category consists of combinations of morphemes of different origin, corresponding to the linguistic category of loanblends, sometimes called hybrid borrowings (Winford 2003; Haspelmath 2009: 39). They are constructed with Spanish and native stems merged into one new word. Typical sixteenth-century examples include noun-noun compounds, referring to new concepts, functions, objects, plants, etc., eg. cihuamadre (cihua-madre; woman-mother, 'nun', literally 'womanmother'; Vocabulario trilingüe: 87r); hostiacalli (hostiah-cal-li, host-house-ABS.SG; Molina 1992, II: 78r) or hostiatecomatl (hostiah-tecoma-tl, host-clay_pot-ABS.SG; Vocabulario trilingüe: 124v) for 'pyx', literally 'host house' and 'host pot', respectively; xocpalguantes (xocpal-guantes, sole_of_the_foot-gloves, 'asagutsu, leather footwear 
worn by Japanese royalty and nobility'; Chimalpahin 2006: 170); aceitunasquahuitl (aceitunas-cuahui-tl, olives-tree-ABS.SG, 'olive tree'; Chimalpahin 2006: 246) or cabildotlaca (cabildoh-tlaca-h, city_council-person-ABS.PL, 'city council members'; Lockhart, Berdan \& Anderson eds. 1986: 107). Other types of blends include instrumental nouns based on the passive voice, e.g., letrachihualoni (letrah-chihua-lo-ni, letter-to_make-NACT-HABIT[INST], 'medium for writing'), for a kind of ink (Sahagún 1950-82, XI: 241), as well as agentives, e.g., candelachiuhqui (candelah-chiuh-qui, candle-to_make-NPRES[AG], 'candlemaker'; Zapata y Mendoza 1995: 380) or, in modern Huastecan Nahuatl, piyonamacaquetl (piyo-namaca-que-tl, chicken-to_sellNPRES[AG]-ABS.SG, 'seller of chickens; Sullivan et al. 2016: 387), including the Spanish onomatopoeic loan piyo 'chicken'. Loanblends are much less attested than loanwords; some of them were clearly created ad hoc and did not enter the language on a larger scale. Diotatzin (dios-tah-tzin, deity-father-small[REV], 'God, the Father'; Pizzigoni ed. 2007: 157), for example, is apparently only attested in our database in a 1726 will from Toluca, and tlacajuez (tlaca-juez, person-judge, 'census taker'), appears only in two sets of late-seventeenth-century annals from Tlaxcala (Townsend ed. 2010: 182; Zapata y Mendoza 1995: 464).

\section{Borrowing of lexical categories}

The pioneering research on early Nahuatl-Spanish contact was done by Frances Karttunen and James Lockhart (1976), who compiled the first listing of Spanish loanwords, analyzing their temporal appearance and phonetic adaptations, and proposed three main phases in the adaptation of Nahuatl to Spanish. This line of research was further developed by Lockhart (1992), who broadened the content of the phases and linked sociocultural changes under European impact. In Lockhart's reconstruction, during the first stage of contact, extending from the arrival of the Spaniards to ca. 1540-1550, the Nahuas relied on the resources of their own language to describe the new, resorting to neologisms and extensions of meaning. During the second stage, from the mid-sixteenth to the mid-seventeenth century, Spanish nouns were borrowed, while in the third stage, from the mid-seventeenth century to the present, many simultaneous changes took place, including the borrowing of verbs and particles, or the adoption of Spanish plural forms and sounds absent earlier in Nahuatl. While the exact nature and timing of language change in Nahuatl is much more complex than in this reconstruction (e.g. Olko \& Szemiński 2018; Olko, Borges \& Sullivan 2018), the general trends proposed by Lockhart referring to the sequence and scale of borrowing of lexical categories hold true.

It was proposed a long time ago that free morphemes such as function words are more easily borrowed than bound morphemes such as inflectional affixes 
(Weinreich 1953: 29-37). In accordance with this principle, different hierarchies for the order of borrowing were developed, such as nouns $>$ other parts of speech > suffixes > inflections > sounds (van Hout \& Muysken 1994: 41). A more recent proposal based on frequency counts was proposed by Matras: nouns, conjunctions $>$ verbs $>$ discourse markers $>$ adjectives $>$ interjections $>$ adverbs $>$ other particles, adpositions $>$ numerals $>$ pronouns $>$ derivational affixes $>$ inflectional affixes (Matras 2007: 61). It has also been argued (Field 2002) that the target language's morphological typology-be it isolating, agglutinating, or fusional-constrains the possibility of borrowing items from another language. Thus, an isolating language can borrow neither agglutinating nor fusional morphology, an agglutinating language borrows agglutinating but not fusional morphology, whereas a fusional language can borrow both agglutinating and fusional morphology. Nahuatl is an agglutinating language, while Spanish is a fusional language, so according to this hypothesis Nahuatl should show strong constraints in borrowing fusional morphology from Spanish. Accordingly, Field proposed $(2002$ : 37-38, 117) the following subhierachy for borrowing in Nahuatl: content items $>$ function words $>$ agglutinating affixes $>$ fusional affixes. While Field has been able to support his hypothesis using a limited corpus of modern Tlaxcalan Nahuatl recordings, this general pattern has also been confirmed by our data. However, whereas Field argues that the Spanish agglutinative plural affix $-\mathrm{s}$ is a sign of limited but present borrowing of agglutinative suffixes, it should be emphasized that it is only found with Spanish loanwords, both in colonial and modern data, so the affix has not been fully incorporated into the morphological system of Nahuatl.

Nahuatl has only four lexical categories: particles, verb words, noun words, and relational words. Spanish, on the other hand, has numerous lexical categories, e.g. noun, verb, adjective, adverb, conjunction, article, and demonstrative. It is clear that through the centuries of contact, Nahuatl has operated within its typological limits and has been able to preserve its lexical and morphological integrity. Incompatible elements, if borrowed, were either reinterpreted as one of the four native lexical classes. As explained in more detail below, this has been the case for Spanish verbs and, especially in the later stages of contact, for adjectives and adverbs, which were reinterpreted as nouns, and for prepositions and conjunctions, which were assigned the category of particles. Only with progressive typological change, beginning slowly in the colonial period and accelerating more recently, new lexical categories, such as prepositions, have emerged in Nahuatl, making the two systems more compatible and bridging some of the constraints of borrowability.

As we can clearly see (Tabs. $1 \& 2$ ), nouns constitute the prevailing category of borrowing in both periods, followed by adjectives, adverbs, verbs, and conjunctions. Apart from nouns, only adjectives, adverbs, prepositions, and verbs show significant presence in the colonial period. While the absolute numbers of differ- 


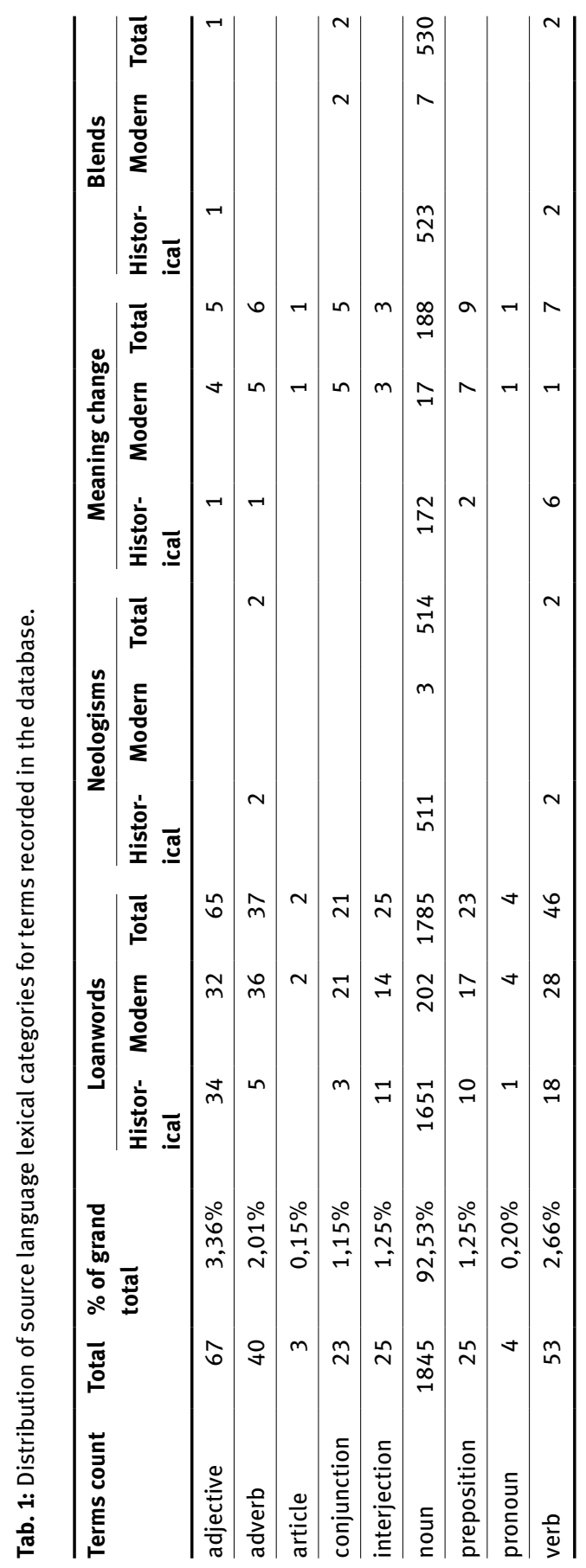




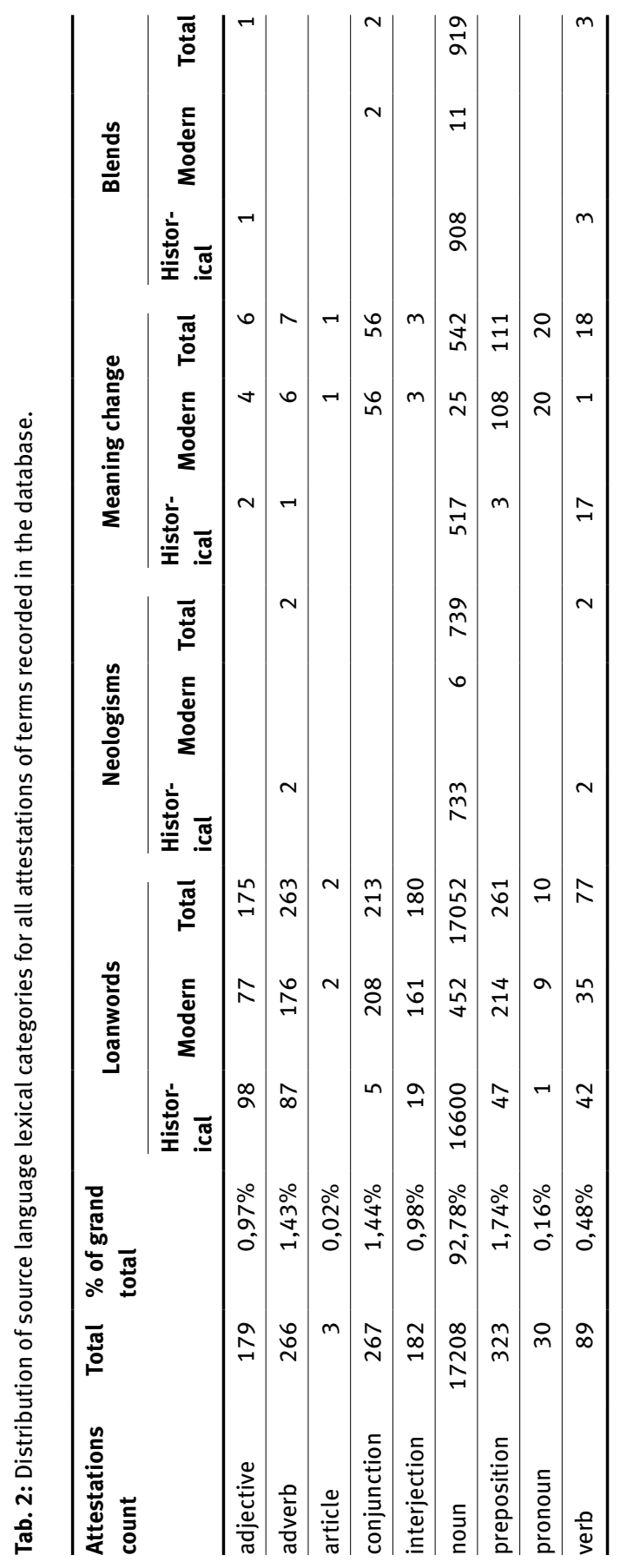


ent borrowed lexical categories cannot be compared due to their highly differing numbers in the respective language systems, what is significant is the change in proportions over time, regardless of the differences in size of analyzed historical and modern corpora. Categories such as adverbs or prepositions are much more frequent in modern Nahuatl. Attestations of articles, conjunctions, and pronouns are almost exclusively confined to the latest stage of contact, and their presence is a sign of diminishing borrowability constraints. As the typological distance between the two languages is reduced, previously non-compatible lexical categories are borrowed more frequently, contributing to the further transformation of Nahuatl and its convergence with Spanish (cf. Olko, Borges \& Sullivan 2018). It is also clear that some loanwords (including nouns, conjunctions, and prepositions) are attested in both periods, attesting to the continuity of using borrowed Spanish lexicon.

The frequency of borrowed nouns with regard to other categories is much bigger than in the modern Tlaxcalan sample analyzed by Field (2002: Tab. 5.1; nouns in this sample are ca. 9 times more frequent than verbs, 7 times more than adjectives and 6 times more than adverbials). This shows a much different pattern for the colonial period in which the borrowing of noun roots indeed was a dominant one (Field 2002: 140). According to Field, the number of borrowed Spanish function words in modern Tlaxcalan Nahuatl was quite striking (Field 2002: Table 5.2; content versus function words ratio $=767$ to 46 terms, but 3421 to 3221 attestations). Function words include Spanish prepositions (de 'of', para 'for, in order to', sin 'without', etc.), coordinating conjunctions ( $o$ 'or', pero 'but'), and subordinating conjunctions (hasta 'until', porque 'because', como 'as, since, like, how', etc.), as well as the complementizer que 'that'. Independent Spanish function words constitute $13.82 \%$ of the total sample and this high rate of frequency reflects their successful adoption into the Nahuatl matrix (Field 2002: 142-143). In our case, conjunctions and prepositions show a significant increase in modern Nahuatl, even though they are also attested in the second half of the colonial period. This especially refers to prepositions, borrowed as particles, and gradually transforming the morphosyntax of Nahuatl (Olko, Borges \& Sullivan 2018). Conjunctions are extremely rare in the colonial sample, most likely because their incorporation indeed entails the transformation of syntactic patterns at the inter-clause level. For example, the conjunction ni... ni... 'neither... nor...' is attested in a Toluca Valley will from 1703:

[1703, Pizzigoni ed. 2007: 241]

ayac aquiquixtilitinemis ni nopilhua ni aqui.

ayac ah-qui-quixtilih-ti-nemi-z ni no-pil-huan ni aquin

no_one NEG-OBJ.3SG-to_take_from-LIG-to_meander-FUT neither POSS.1SGchild-POSS.PL neither anyone

'No one is to go about taking it from him, neither my children nor anyone else.' 
The conjunction que introducing an indirect reporting of speech is already attested in 1750:

[1750, Calimaya, Lockhart ed. 1991: 108]

sa nima otlananquililique muchtintzitzi $s^{\text {res }} g^{\text {res }}$ pasados yca comun que ma momaca ynin $D^{s}$ ypiltzi tlen quitlani.

zan niman $\mathrm{o}=$ tlananquililih-que-h moch-tin-tzi tzin señores gobernadores pasados i-ca comun que mo-maca inin dios i-pil-tzin tlen qu-ihtlani

just immediatly ANTEC=to_answer-NPRES-PL all-PL-PL small[REV] lords governors former POSS.3SG-means[REL] commoners that REFL.3SG-to_give_to this god POSS.3SG-child-small[REV] what OBJ.3SG-to_ask_for

'Then immediately all the honorable past governors and ordinary people replied to him: «Let this child of God be given what he asks».'

It is now commonly used in modern Nahuatl:

[2014, Donaciano Lucas Hernández, Xilitla, San Luis Potosí]

Yohui-h i-ca inin-tatah-huan quin-illia-h que ya qui-piya-h ce tlanehuilil-li.

to_go-PL POSS.3SG-means[REL] POSS.3PL-father-POSS-PL OBJ.3PL-to_tell-PL that already OBJ.3SG-to_have-PL one agreement-ABS.SG

'They go and tell their parents that they have the agreement.'

Conversely, the incorporation of prepositions mainly had an impact at the interclause level, but some of them, such as para, have also influenced intra-clause constructions. The following examples illustrate these different functions that para began to perform in Nahuatl over time, from its role corresponding to the Spanish preposition to a subordinate conjunction introducing a dependent clause:

[1653, McAfee Collection; Anderson, Berdan \& Lockhart 1976: 174]

$\begin{array}{lll}\text { Çacatl } & \text { para } & \text { ycabalyo } \\ \text { zaca-tl } & \text { para } & \text { i-caballoh } \\ \text { grass-ABS.SG } & \text { for } & \text { POSS.3SG-horse }\end{array}$

'grass for his horse'

[1750, AGN Tierras 2541, exp. 11; Lockhart 1991: 108]

$\begin{array}{llll}\text { quenami } & \text { mitlania } & \text { se pedaso } \\ \text { quen-amih } & \text { m-ihtlania } & \text { ce pedazo } \\ \text { how-to_exist[STAT] } & \text { REFL.3SG-to_request } & \text { one piece }\end{array}$




\begin{tabular}{|c|c|c|c|}
\hline tlali & para & campa & quitucas \\
\hline tlal-li & para & cam-pa & qui-toca-z \\
\hline land-ABS.SG & for & where-toward[RTL] & OBJ.3SG-to_plant-FUT \\
\hline ome & yey & grano & tloli \\
\hline ome & yei & grano & tlaol-li \\
\hline two & three & grain & shelled_corn ABS.SG \\
\hline
\end{tabular}

[2012, Tepoxteco, Chicontepec, Veracruz]

qui-illia para ma qui-caxani quena

OBJ.3SG-to_tell that OPT OBJ.3SG-to_loosen yes

'He tells him to really heal her.'

\section{Thematic categories of borrowed lexicon}

A widely accepted general rule regarding the main thematic constraint on lexical borrowing states that 'core vocabulary' is very rarely (or never) borrowed, especially in an early phase of contact (e.g. Thomason 2001: 71-72; Haspelmath 2009: 36). Defining what constitutes 'core' or 'basic' vocabulary is more difficult, especially in cross-cultural and cross-linguistic contexts. In practical terms, linguists often rely on Swadesh's (1971) list of 'non-cultural vocabulary' containing words that are resistant to borrowing. As a recent broad cross-linguistic study has shown, words belonging to different semantic fields show highly varying borrowing rates, but different languages display a remarkable degree of consistency in terms of rates of borrowability related to semantic fields. In other words, despite cross-linguistic differences, most languages tend to borrow more words into similar fields, whereas similar fields appear to be more resistant to borrowing. The semantic fields most affected by borrowing belong to religion and beliefs, clothes, and household, corresponding to domains most affected by intercultural contact (Tadmor 2009: 64). Most resistant to borrowing appear to be terms referring to kinship, body, spatial relations, and sense perception; even less borrowable are functions words and deictics-especially those related to spatial organization-as well as interrogative pronouns (Tadmor 2009: 66). In the sample of modern Tlaxcalan Nahuatl analyzed by Field (2002: Table 5.6) 'concrete' nouns are much more widely borrowed than abstract nouns, referring to state, properties, activities, etc.

In our database, attestations related to contact-phenomena were classified according to several thematic categories, assuming that some of the items, depending on their semantic field, could be associated with more than one category, for 
example as belonging to 'people' and 'officials' (Tabs. $3 \& 4$ ). Often one specific loanword referring to a key element of colonial life became the basis for creating a wide spectrum of new term. For example, from the word caballo, 'horse', derive a number of terms used both in colonial and modern Nahuatl, such as caballohuica 'to take the horse', caballoicpalana 'to unsaddle a horse', caballopehpechtli 'a saddle' literally 'horse mat', caballopehpechtlazaliztli or caballopehpechtomaliztli 'action of removing a horse's packsaddle', caballotemmecayotl 'reins', literally 'something pertinent to horse's mouth rope', caballotencuetlaxilpia 'to bridle a horse', literally 'to bind a horse's mouth with leather', caballotenilpia 'to bridle a horse', literally vto bind a horse's mouth', caballotepiton 'pony', literally 'small horse', caballotlamamalpehpechanaliztli 'action of removing a horse's packsaddle', caballotlamamalpehpechanqui, caballotlamamalpehpechtonqui or caballotlamamalpehpechtomani 'someone who removes a horse's packsaddle', caballotlamamalpehpechantli or caballotlamamalpehpechtlatlaxtli, both meaning 'horse with its packsaddle removed', caballotlamamalpepechtontli 'horse with a packsaddle', caballotlapachiuhcayotl 'saddle pad or horse blanket', literally 'something pertinent to a horse cover', and caballotlatlalochtia 'to race horses'.

The highest number of new terms in the colonial period refers to the religious sphere (concepts and procedures counted together with officials and titles associated with the area of the Christian cult) as well as to artifacts and objects usually associated with European imports. New offices and titles, place names, plants, and animals also form a significant category, followed by legal terms and units of measure. In terms of the number of attestations, religious concepts, and procedures are again most frequent followed by officials, titles, calendar terms and artifacts or objects. In the modern sample, most borrowings, both with regard to distinct terms and the number of attestations, belong to the category of 'other', followed by artifacts/objects and people/groups/organizations. The group 'other' embraces terms not traditionally associated with the domains of contact. Many of them represent substitutive borrowing and extend to core vocabulary, such as kinship, physical activities, the physical world, the senses and emotions. Good examples of substitutive borrowing were produced from visual elicitation of speakers of modern Huastecan Nahuatl:

Niquitta ezte..., atl, oncah miac ezteh..., cerroz, yeloh.

I see, eh..., water, here are many eh..., hills, ice.

Niquinitta ome eztreyaz huehhuextiqueh, niquitta ce arbol huactoc.

I see two big stars, I see a dry tree. 


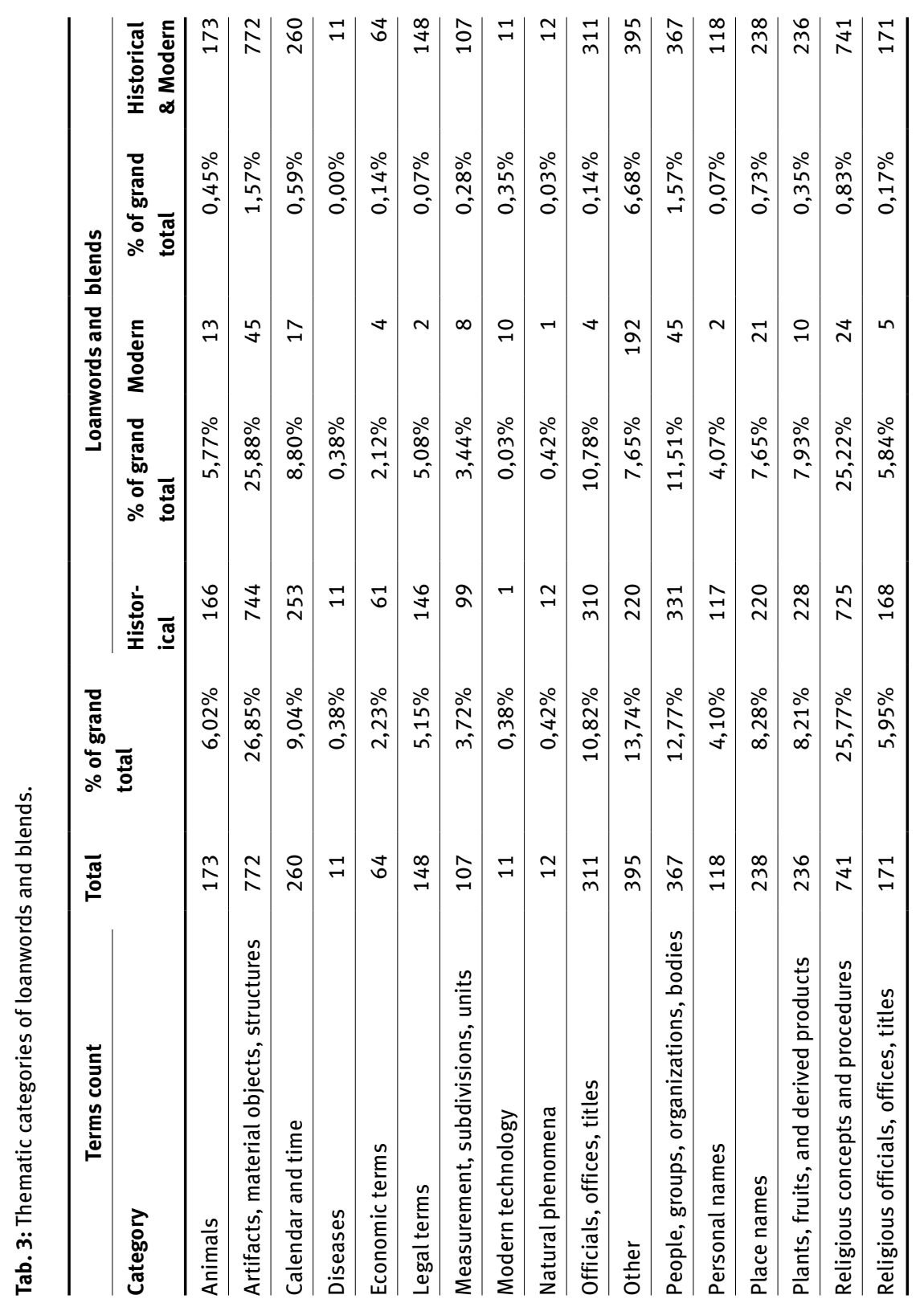




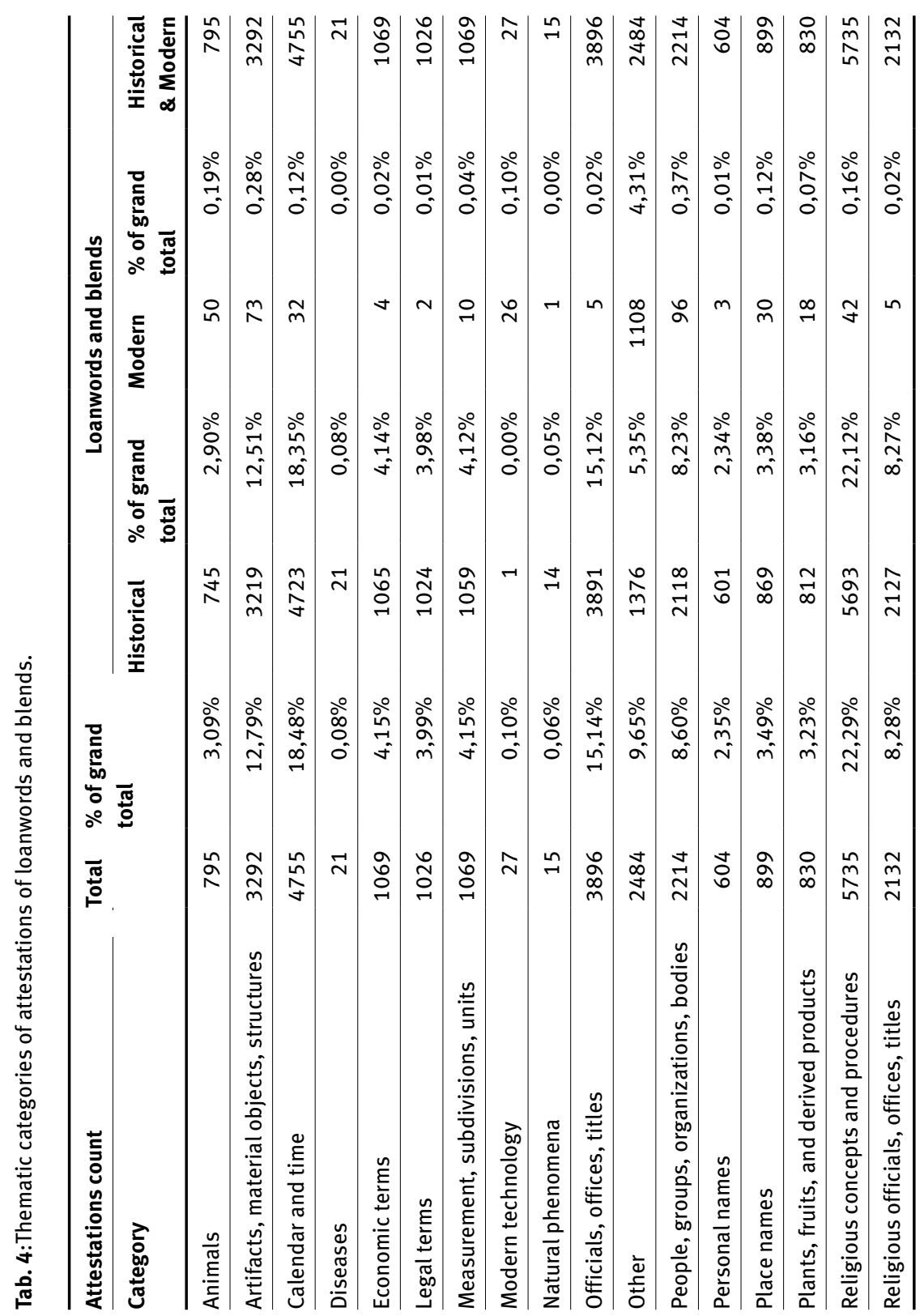


In the two examples, some core vocabulary items belonging to the physical world, like hill, ice, stars or tree have been replaced with Spanish loanwords. Such patterns of borrowing attest to an accelerating process of language change, widespread bilingualism and the shift to Spanish, and can be better understood in the context of the mechanisms and motivation of borrowing discussed in the last section of this study.

\section{Phonological adaptations of loanwords}

The sound system of colonial Nahuatl differs from that of Spanish in terms of, e.g., the lack of distinctive voicing in consonants, the absence of equivalents of individual sounds found in Spanish, such as the interdental fricative /f/ and the liquid /r/, as well as phonotactic patterns. These differences are reflected in the assimilation of Spanish loanwords. The most common kind of adaptation, from early through late contact, involves the substitution of a Spanish sound with a close/closest equivalent in terms of place or manner of articulation. The analysis of colonial orthography has demonstrated that substitutions of specific Spanish consonants absent in Nahuatl could involve several equivalent sounds (Karttunen \& Lockhart 1976). At the same time, the orthography in written sources (cf. Lockhart 1992: 294-298) suggests that originally absent sounds were gradually introduced into Central Nahuatl through the colonial period, especially among bilingual speakers. It is now common among modern bilingual speakers to use the complete Spanish phonetic inventory in loanwords or in code switching. However, in more peripheral and traditional variants, such as Huastecan Nahuatl, phonetic adaptations of Spanish loanwords continue to be not much different from those of colonial Central Nahuatl. Examples of typical substitutions present in colonial sources are given in Tab. 5.

Tab. 5: Phonetic substitutions in Spanish loanwords.

\begin{tabular}{ll}
\hline Type of substitution & Examples \\
\hline $\mathrm{b}[\mathrm{b}] \rightarrow \mathrm{p}[\mathrm{p}], \mathrm{hu}[\mathrm{w}]$ & $\begin{array}{l}\text { tumba } \rightarrow \text { tonpa } \\
\text { caballo } \rightarrow \text { cahuayo }\end{array}$ \\
\hline $\mathrm{d}[\mathrm{d}] \rightarrow \mathrm{t}[\mathrm{t}], \mathrm{I}[\mathrm{l}][\mathrm{d}], \mathrm{r}[\mathrm{r}]$ & $\begin{array}{l}\text { alcalde } \rightarrow \text { alcalte } \\
\text { diputado } \rightarrow \text { teputado, repotado } \\
\text { medio } \rightarrow \text { metio, melio, merio }\end{array}$ \\
\hline $\mathrm{f}[\mathrm{f}] \rightarrow \mathrm{p}[\mathrm{p}]$ & firma $\rightarrow$ pilman \\
\hline $\mathrm{g}[\mathrm{g}] \rightarrow \mathrm{c}[\mathrm{k}], \mathrm{x}[\mathrm{d}, \mathrm{s}[\mathrm{s}], \mathrm{j}$ (probably pronounced []$])$ & $\begin{array}{l}\text { goznez } \rightarrow \text { coznez } \\
\text { clérigo } \rightarrow \text { clerico }\end{array}$ \\
\hline
\end{tabular}


Tab. 5 (continued)

\begin{tabular}{|c|c|}
\hline Type of substitution & Examples \\
\hline $\mathrm{g}[\mathrm{x}] \rightarrow \mathrm{x}[]], \mathrm{s}[\mathrm{s}], \mathrm{j}$ (probably pronounced []$]) ;$ & regidor $\rightarrow$ rexitor, rexidor, residor, rejildo \\
\hline $\mathrm{j}[\mathrm{x}] \rightarrow \mathrm{x}[]]$ & juntera $\rightarrow$ xontera \\
\hline $\mathrm{II}[\Lambda] \rightarrow \mathrm{y}[\mathrm{j}]$ & caballo $\rightarrow$ cavayo[h], cabayoh \\
\hline$\tilde{n}[n] \rightarrow y[j]$ & gañán[es] $\rightarrow$ cayanis \\
\hline$r[r] \rightarrow I[l][t], I I[l][t] ; n[n]$ & $\begin{array}{l}\text { firma } \rightarrow \text { pilman } \\
\text { sombrero } \rightarrow \text { sombreno } \\
\text { Contreras } \rightarrow \text { Contrellas }\end{array}$ \\
\hline $\mathrm{s}[\mathrm{s}] \rightarrow \mathrm{x}, \mathrm{j}$ (pronounced []]) & $\begin{array}{l}\text { solar } \rightarrow \text { xolal, jular } \\
\text { señora } \rightarrow \text { xinola } \\
\text { peso } \rightarrow \text { pexo }\end{array}$ \\
\hline $\mathrm{v}[\mathrm{b}] \rightarrow \mathrm{hu}[\mathrm{w}]$ & llave $\rightarrow$ yahui \\
\hline $\begin{array}{l}o[o][u] \rightarrow u[o][u], u[o][u] \rightarrow o[o][u] \\
\text { e }[e] \rightarrow i[i]\end{array}$ & $\begin{array}{l}\text { tesorero } \rightarrow \text { desurello } \\
\text { lunes } \rightarrow \text { lones } \\
\text { estola } \rightarrow \text { ystula } \\
\text { leche } \rightarrow \text { lechi }\end{array}$ \\
\hline
\end{tabular}

As a result of different phonotactic patterns found in Nahuatl and Spanish, typical changes include consonant and vowel deletion and insertion. In the case of deletion, we deal with the loss of sounds that are disallowed in the wordfinal position as well as with the simplification of consonant clusters absent in Nahuatl. Epenthesis usually involves the insertion of nasals at the end of syllables or in the word-final position (which was also typical of Nahuatl words) and of vowels facilitating the pronunciation of difficult consonant clusters. Examples of such processes are given in Tab. 6 .

Tab. 6: Phonological processes in Spanish loanwords.

\begin{tabular}{ll}
\hline Type of phonological process & Examples \\
\hline Consonant deletion & $\begin{array}{l}\text { regidor } \rightarrow \text { rejildo } \\
\text { hospital } \rightarrow \text { opidal }\end{array}$ \\
\hline Vowel deletion & memoria $\rightarrow$ memori \\
& vicario $\rightarrow$ vicari \\
\hline Consonant epenthesis & cofradia $\rightarrow$ confrarias \\
& sitio $\rightarrow$ sintiyon \\
\hline Vowel epenthesis & cruz $\rightarrow$ coloz, coroz \\
& trigo $\rightarrow$ terigo \\
\hline
\end{tabular}




\section{Morphological adaptations of loanwords}

The morphological adaptations of Spanish loanwords into Nahuatl were driven by the differing typological profiles of the two languages as well as by the underlying differences in their respective lexical and grammatical categories. Both of these discrepancies between the two linguistic systems are reflected in the widespread and extensive nativization of loanwords. Nahuatl is an agglutinative polysynthetic language, operating with chains of morphemes and a large number of affixes carrying grammatical information. Thus, once a loanword was incorporated into Nahuatl, it could be subject to use with the complete range of derivational and inflectional affixes available in the target language. Due to the agglutinating nature of Nahuatl, chains of affixes are constructed incrementally, with each successive affixation modifying the precedent form, its meaning and grammatical functions.

At the most basic level, Spanish loanwords were incorporated into older Nahuatl as one of three of the latter's four lexical categories: noun, relational word, and particle. Spanish nouns were borrowed into Nahuatl as noun roots, and as such, underwent the standard nominal morphological processes. Verbs too, were borrowed as noun roots and only then re-verbalized using Nahuatl's verbing suffixes. Spanish conjunctions were usually converted into Nahuatl particles, while prepositional phrases, especially those expressing space relations, were reinterpreted, especially in the colonial period, as relational words. For example, a la China 'to China [Philippines]' was incorporated into Nahuatl as a single word, alachina and interpreted as a relational word. In modern Nahuatl, as a result of contact-induced typological change, many relational words have been transformed into a new grammatical category modeled on Spanish: they have become prepositions (Olko, Borges \& Sullivan 2018).

Usually Spanish loan nouns are incorporated into Nahuatl as noun roots ending in a consonant, which is either preserved from the source word, as for example in cruz, or a final glottal fricative $\mathrm{h}$ is added to loan nouns originally ending in a vowel, e.g. caballo 'horse' becomes cahuayoh. The Nahuatl absolutive suffixes $-t l$, -li, and -tli were added to Spanish nouns only in rare cases. Thus, calzón, 'underwear' becomes caltzomitl, through the addition of a supporting $i$ and the absolutive suffix, -tl (caltzom-i-tl, underwear-SUP-ABS.SG). A similar attested case includes anillotl (aniyo-tl, ring-ABS.SG, from anillo, 'ring'), indicating a tube used in the manufacture of golden objects (Florentine Codex, Book 9: 77). However, this loanword use implies a meaning change because the form anillo, meaning 
'ring', is widely attested in colonial Nahuatl sources without an absolutive ending. ${ }^{3}$ Another interesting 1985 example is that of the modern usage of the Spanish word antiguo, transformed to antihuatl (antihua-tl, ancient-ABS.SG) meaning 'ancient one'. The absolutive suffix - $l i$, normally used with native roots ending in $l$, is found with the borrowed noun panal 'beehive', resulting in panalli (panal-li, beehive-ABS. $\mathrm{SG}$ ). Attested examples of added - tli, normally used with native roots ending in a consonant (except $l$ ) include camixatli from camisa, 'shirt' (camizah-tli, shirt-ABS. SG), capatli from Spanish capa (capah-tli, cape-ABS.SG), cuentaxtli from Spanish cuentas, or 'counts' but meaning 'rosary' (cuenta-x-tli, count[PL]-ABS.SG), and pexotli from peso for 'weighing scale' (pexoh-tli, scale-ABS.SG). Nahuatl possessive prefixes and the plural possessive suffix are very commonly used with Spanish loan nouns; for example, itlazoanima (i-tlazoh-animah, POSS.3SG-precious-soul, 'his precious soul'; Doctrina Christiana 1548: fol. LXXIIr) and iregidorhuan (i-rehidorhuan, POSS.3SG-councilman-POSS.PL, 'his councilmen'; Zapata y Mendoza 1995: 472).

Loanwords can also undergo compounding with native nouns forming blends; for example, cihuadiablomeh (cihua-diabloh-meh, woman-devil-ABS.PL, 'female devils'; Bierhorst 2011: 15) and vinocalli (vinoh-cal-li, wine-house-ABS.SG, 'tavern'; Molina 1992, I: 20r). An example of compounding with a relational word is tocapi-llacaltenco (to-capiyah-cal-ten-co, POSS.1PL-chapel-house-edge-place[RTL], 'at our chapel's door'; Zapata y Mendoza 1995: 54). Loan nouns can be compounded with the root -tzin to produce the reverential form, as for example in ivisperatzin (i-vizperah-tzin, POSS.3SG-eve-small[REV], 'on the eve of'; Zapata y Mendoza 1995: 482).

Compounding includes forms created with patientive nouns of pertinence and agentive nouns of possession. Thus, gobernador 'governor', when compounded with the absolutive form of the patientive noun root -yotl creates the abstract noun gobernadoryotl (gobernador-yo-tl, governor-pertinent[PATN]-ABS.SG, 'governorship'; Zapata y Mendoza 1995: 264). Compounds with -yo in the possessive form nouns of inherent possession, as in isolaryo (i-zolar-yo, POSS.3SG-house_plotpertinent[PATN], 'its (inherently possessed) house lot'; Cline \& León-Portilla eds. 1983: 46). Loans can be compounding with the preterite agentive of this same root, -yoh, to create the preterite agentive of possession; for example, the Spanish noun cilantro 'coriander', which is adapted phonetically in Huastecan Nahuatl as colantoh, is used to create colantohyoh (colantoh-yoh, coriander-owner[AG]), meaning a 'dish made with coriander' (Sullivan et al. 2016: 117); and fuerza

3 The underlying form for this word is probably anillo-yo-tl (ring-pertinent[PATN]-ABS.SG), with the yo- morpheme that is used to create derived meanings from basic, concrete nouns. The double sound sequence [jojo] in [anijojott] might have been reduced through the process of haplology. 
'strength/effort' is used to produce fuerzahyoh (fuerzah-yoh, effort-owner[AG], 'difficult work'; Sullivan et al. 2016: 188). The other two agentives of possession, -eh and -huah, can also compound with loans, as in hospitaleh (hospital-eh, hospital-owner[AG], 'the one who has a hospital, hospital owner'; Chimalpahin 2006: 280) or coronahuah (coronah-huah, crown-owner[AG], 'crowned person', literally ‘owner of a crown'; Molina 1992, I: 30v; II: 24v).

Loan nouns are also often incorporated into verbs. They can function as objects, as in candelanamaca (candelah-namaca, candle-to_sell, 'he sells candles'; Florentine Codex, Book 10: 91). And it is not uncommon for incorporated loanwords to act as adverbial modifiers of verbs, as in valmocruztecac (hual-mo-cruz-teca-c, IND-REFL.3SG-cross-to_spread-NPRES, 'it was spread in the shape of a cross'; Anales de Juan Bautista: 316). Spanish loanwords are also commonly verbalized, including both nouns and verbs taken from the source language. The inceptive verbing suffix - $t i$ is very productive with loan nouns. From alcalde 'judge' we have oalcaldetiya ( $\mathrm{o}=$ alcaldeh-ti-ya-h, ANTEC=judge-VRIPFV-PL, 'they served as judges'; Lockhart, Berdan \& Anderson 1986: 92). The suffix can also be employed along with another inceptive verbing suffix, $-y a$, as in manzohtiya (manzoh-ti-ya, tame-VR-VR, 'for an animal to become tame'; Sullivan et al. 2016: 293), from the Spanish manso 'tame, not aggressive'. Spanish nouns are also often verbalized with another - $t i$ suffix, which creates verbs meaning 'to have [the compounded noun]'; and when this new verb is combined with the causative suffix $-a$, it conveys the meaning of 'to provide someone or something with [the incorporated noun]', literally 'to cause someone to have something.' This is the case with the often-attested form firmatia 'to sign something', as in mofirmatique (mo-firma-tih-que-h, REFL.3PL-signature-VR.to_have-NPRES-PL, 'they set down their signatures,' literally 'they provided themselves with signature'; Lockhart, Berdan \& Anderson eds. 1986: 87). And from camisa, 'shirt', we have camisatia (camisah-ti-a, shirt-VR.to_have-CAUS, 'to put a shirt on', literally 'to provide oneself with a shirt'; Molina 1992, II: 12r). In some cases the derivational process is longer, as with cajonyotia ('to put something in a chest'), in which the Spanish noun cajón is first transformed into an abstract noun cajonyotl and then verbalized, as we can see in the following example (the causative $-a$ is deleted before the addition of the benefactive suffix -lia):

[Zapata y Mendoza 1995: 608]

ça niman quimocaxoyotilique yn tecroz

zan niman qui-mo-caxon-yo-ti-lih-que-h

just immediately OBJ.3SG-REFL.3PL-chest-pertinent[PATN]-VR.to_have-BEN-NPRES-PL 'Then they put [a stone cross] in a chest.' 
A very common form of lexical conversion, especially during later stages of contact, is the transformation of borrowed Spanish verbs, reanalyzed as noun roots, into intransitive verbs through the addition of a verbing suffix. One of the first and most lasting cases of this phenomenon occurred with the verb pasear 'to take a stroll'. The causative form of pasearoa (or pasealoa) is pasearoltia (pasealoltia) and it is attested in the early seventeenth century. Chimalpahin uses the form oquipassealoltique (o=qui-paseal-o-ltih-que-h, ANTEC=OBJ.3SG-to_stroll-VR-CAUS-NPRES-PL 'they paraded him,' literally 'they caused him to stroll'; Chimalpahin 2006: 272). Nouns that are verbalized using -o $a$ also have a benefactive form that is achieved through the suffixes-huia or-huilia.This producesa transitive verb meaning 'toapply an object indicated by the incorporated noun to someone or something. In contact vocabulary it is applied both to Spanish nouns and, less frequently, to verb roots reinterpreted as nouns. Examples of the latter include the contemporary attested ofrecerhuilia in quiofrecerhuiliah (qui-ofrecer-huilia-h, OBJ.3SG-to_make_an_ offering-BEN-PL, 'they are making an offering to [the deity'; 2014-P) or pintarhuilia in quipintarhuilia (qui-pintar-huilia, OBJ.3SG-to apply painting-BEN, 'he is painting [his house]', literally, 'he is applying painting to his house'; Sullivan et al. 2016: 382). Spanish noun roots converted into - huia verbs are abundantly attested since the colonial period. Thus, we find arcabuzhuia ('to use a musket on someone') in ocalcapozhui (o=c-arcabuz-huih, ANTEC=OBJ.3SG-musket-BEN, 'he used a musket on [one of our fathers]'; Chimalpahin 2006: 260) and tlacamisahuia (tla-camizah-huia-h, OBJ.NHUM-shirt-BEN-PL, 'they wear shirts', literally 'they apply shirts to things'; Chimalpahin 2006: 188). An interesting example attested in 1613 is that of palosdahuia in nechpalosdahuiya (nech-palos-da-hui-ya, OBJ.1SGblows-he/she_gives-BEN-IPFV, 'she was giving me blows'; Karttunen \& Lockhart eds. 1976: 105). This verb is formed directly from the utterance palos $d a$ 'he/she beats [someone]', from the expression dar palos 'to beat someone', literally 'to give blows'. Thus, palos $d a$ was first interpreted as a noun by the Nahuas, then verbalized, and finally converted into a benefactive verb. A modern example is icxipatarahuia 'to kick someone':

[Sullivan et al. 2016: 222]

Angel quiicxipatarahhuia ïcniuh pampa quicuilih iahahuil.

Angel qui-icxi-patarah-huia i-icni-uh pampa qui-cui-lih i-ahahuil

Angel OBJ.3SG-foot-a_kick-BEN POSS-3SG-sibling-POSS.SG because OBJ.3SG-to_take-BEN POSS.3SG-toy

'Angel kicked his sibling because he took his toy from him'.

Finally, yet another verbing suffix used with loan nouns is the inceptive -ihui. An example of its use is provided by the verb derived from the loanword pompón, 
'pompom' (pomponihui, pompon-ihui, pompom-VR, 'for a tree or plant to become leafy'). Another derivative from this Spanish word is pompontic (pompon-ti-c, pompom-VR-NPRES[AG], 'something spongy'). In this case, the inceptive verber - $t i$ was added to pompón, producing the intermediate form pomponti (pompon-ti, pompom-VR, 'to become spongy', literally ‘to become like a pompom'). The verb is then put into the preterite tense and reinterpreted as a preterite agentive noun, which in Nahuatl functions like an adjective:

[Sullivan et al. 2016: 392]

Ne coxtalli nelpompontic, huan naman ayoccualli.

Ne coxtal-li nel-pompon-ti-c, huan naman ayoc-cualli.

That bag-ABS.SG truly-pompom-VR-NPRES[AG] and now no_longer-good

'That sack is very spongy, and now it's no longer any good'.

Yet another adaptive process operating with loanwords is reduplication. As Richard Andrews explains, Nahuatl nouns, both animate and inanimate, can be reduplicated to show plurality in two ways. A noun whose first syllable is reduplicated with a long vowel, regardless of the vowel length of the original syllable, is know as an affinity nounstem, and it refers to a group of entities that form part of a cohesive group. But a noun that reduplicates with a short vowel and ends with a glottal stop or fricative, can be either a distributive stem, referring to each of the entities in a group, or to a group of differing entities (Andrews 2003: 110-112). Distinguishing between these forms of reduplication is extremely difficult in textual documents since neither vowel length nor the glottal stop or fricative were represented consistently in the writing system. Reduplication can be used to indicate the plural of borrowed Spanish nouns. For example, even though the glottal stop or fricative is not marked, cacapitanmeh seems to be a distributive reduplication:

[Anales de Juan Bautista 2001: 180]

...in domingotica quimittaz in cacapitanme

in domingo-ti-ca quim-itta-z in cah capitan-meh

SR Sunday-LIG-means[RTL] OBJ.3PL-to_see-FUT SR DISTR captain-PL

'...on Sundays he will see each of the captains.' (or: 'different captains')

Distributive reduplication can also refer to periodicity, as in bibiernes (vih viernes, DISTR Friday, 'on [different or subsequent] Fridays'; Townsend ed. 2010: 128). In modern Huastecan Nahuatl, the Spanish noun carrera ('race') is compounded with the diminutive-reverential root -tzin and then reduplicated with a glottal fricative, in this case conveying more the idea of intensity than distribution, to form a 
word with an adverbial function: cahcarrerahtzin (cah carrerah-tzin, INTS racesmall[REV], 'very quickly').

In terms of standard patterns of pluralization, Spanish loan nouns take either the Spanish plural suffix $-s$, one of Nahuatl plural suffixes or both, as in nahui alcaldesmeh (nahui alcalde-s-meh, four judge-PL-PL, 'four judges'; Zapata y Mendoza 1995: 374). As we have seen, prepositional phrases from Spanish are reanalyzed in Nahuatl as relational words. Spanish loan nouns and Spanish verbs that are reanalyzed as noun roots are subject to all of the morphological processes available to native Nahuatl nouns. These include absolutive and possessive inflection; compounding and incorporation; verbalization, and subsequently causative, benefactive, and agentive derivations; and reduplication. Additionally, loan nouns receive Spanish and Nahuatl plural suffixes, either separately or simultaneously.

\section{Conditions, motivations and patterns of introduction of loanwords}

What kinds of processes and needs drove the introduction of Spanish loanwords into Nahuatl through time? The driving factors can be language-external and language-internal, the latter being linguistic constraints such as typological distance. While Nahuatl and Spanish at the time of contact in the sixteenth century were very remote typologically, this distance has been significantly reduced due to long-term convergence and the gradual adoption in Nahuatl of a more analytic characteristic that facilitates massive borrowing in its modern variants. Even more relevant for our context are extralinguistic factors that can help explain the types, intensity and results of borrowing. Thomason and Kaufman (1988), for example, emphasize the role of the intensity and length of contact, the relative number of speakers of each language as well as cultural, social, political, and economic factors. Without doubt, one of the most relevant factors is the intense and prolonged exposure to language contact (Matras 2007:34; Matras 2009: 164-165). Other possible reasons of borrowing, also relevant for Nahuatl, are the forms of dominance of Spanish, including colonial and postcolonial situations, the innovations associated with culture contact, and possible lexical 'gaps' in the indigenous language, prestige of the colonial/national language as well as related ideologies and attitudes and, finally, varying proficiencies in the national/dominant and heritage languages.

A basic distinction divides loanwords into cultural borrowings, designating new objects and concepts, and core borrowings, creating duplicate meanings, for which native words already exist (Myers-Scotton2002; Haspelmath 2009). However, while cultural loans have been called 'loanwords by necessity', all languages have 
sufficient creative resources to make up new words for new concepts (Haspelmath 2009: 47). Important criteria include language efficiency, the degree of familiarity with the donor language, and language attitudes such as purism, which hinder the introduction of loanwords. In the early stages of Nahuatl-Spanish contact, bilingualism was extremely limited, while purist attitudes were probably not an important factor. Nonetheless, the borrowing of Spanish lexicon was widespread and quick. The earliest known dated text in Nahuatl, a 1543 order against idolatry from Tlaxcala, contains a considerable number of loanwords and phrases (alguacil, gobernador, misa, domingo, viernes, sabádo, quatro temporas) and even a lexical calque for Anno Domini ("yn isihu ỹ t.", in ixiuh in totecuiyo; Olko \& Brylak 2018). The semantic domains of early borrowing form clear functional sets, like the basic municipal offices or terminology related to Christianization in the 1543 document. While it is assumed that if few members of a given community speak the donor language, native neologisms and meaning shifts are more likely to be used for the new concepts. This does not seem to be the case of Nahua communities in view of limited bilingualism and a widespread presence of loanwords. However, we should consider three possible factors. Firstly, both in the colonial period and in modern times Spanish was associated with higher prestige, for political and economic reasons. Secondly, bilingual individuals in indigenous communities operated as cultural brokers and were an important source of language innovations: these embrace notaries, translators, some officials, teachers, and native intellectuals. Also, the role of Spaniards permanently residing in Nahua communities should not be underestimated: they included settlers, merchants, entrepreneurs, and friars/priests. The third factor to be considered is language efficiency. Although Nahuatl has the natural propensity to create new words through chains of morphemes, neologisms are usually very long words; it is also challenging to establish their unambiguous meaning among members of a community or, with even more difficulty, outside a community. It is possible that using shorter loanwords from Spanish became eventually more efficient in the communication process. It was facilitated by the gradually growing number of indigenous persons having some level of proficiency in Spanish.

Our database shows that a huge number of neologisms or native creations was short-lived, probably limited to 'translation laboratories' and dictionary compilations. Numerous neologisms and even blends reported in dictionaries, such as the works of Molina, cannot be taken as a straightforward reflection of language use in native communities. Another example is the work of a native annalist living in Mexico-Tenochtitlan, don Domingo de San Anton Muñon Chimalpahin Quauhtlehuanitzin, who employs an enormous amount of both Spanish loanwords and Nahuatl neologisms (many of which he could have been created himself ad hoc). However, most of these terms do not appear to have been in use among 
other speakers of Nahuatl, especially those living outside the capital city. He also introduces some loanwords belonging to the core vocabulary, whose appearance significantly predates attestations in other native sources. For example, he uses a Spanish kinship term, primo hermano 'first cousin (male)' (iyachton yPrimo hermano, 'her older brother once removed, her first cousin') once in reference to a native noblewoman, doña Agustina de Guzmán from Coyoacan (Chimalpahin 2006: 252), well ahead of the more general patterns of borrowing.

Many neologisms were created ad hoc as explanations of Spanish words or names for new objects and concepts and did not spread among larger groups of indigenous people. The same can be said for a large portion of Spanish loanwords that did not become part of the language repertory of the broader community of speakers of Nahuatl. The degree of the correspondence between dictionary repertories and language use can be verified with data found in mundane texts written by the Nahuas themselves. While the loanword dictionary does not contain neologisms, it clearly illustrates some aspects of this process by showing the existing or lacking correspondence between the contact terminology contained in ecclesiastical or lexicographic sources and their actual use as reflected in mundane documents.

The lexical 'tension' between neologisms and their corresponding Spanish loanwords is reflected in their relatively frequent use in traditional doublets, constructions in which two separate words or phrases are paired to form a single metaphoric unit, the paired elements being either synonyms or antonyms. In the context of language contact, the function of native creations or neologisms in such pairs was to explain the meaning of the loan element. An early example of the use of a Nahuatl-Spanish doublet comes from the Nahua periphery in Sonocusco: tohuelitiliz topoder [written as touelitiliz topoler], meaning 'our power' (petition from Huehuetlan, Soconusco, 1562, AGI, Guatemala 52, fol. 35r), in which the Nahuatl term huelitiliztli, based on the verb hueliti 'to be possible,' became an approximation of the Spanish word poder, 'power'. A common neologism used in bilingual doublets is the expression tetlechipahualoyan and its variant tletechipahualoyan, 'the place were people are purified by fire', coined to convey the Christian concept of purgatory. It continued to be employed well into the seventeenth century even though the Spanish word purgatorio is already attested in one of the testaments of Culhuacan 1580 (as purcatori). The latest identified attestation of the doublet is found in a 1739 will from Ixtenco, Tlaxcala: S. ${ }^{n}$ to Purgatorio yn tlachipahualoya[n], 'Holy Purgatory, a place of purification'. Yet another bilingual doublet is the abovementioned iyachton yPrimo hermano ('her older brother once removed, her (male) first cousin'), which is quite interesting because the third-person singular possessive prefix $i$ - on the first word of the loan phrase primo hermano, '(male) first cousin', indicates that the phrase as been reanalyzed in Nahuatl as a single word. Moreover, doublets resembling those of the colonial period can be found in modern 
Nahuatl, as in a 2014 recording from San Miguel Xaltipan, Tlaxcala in which the particle oc is paired with its Spanish synonym, todavia: Huan oc todavia techilliah que amo cualli cah totequih, 'And still they tell us that our work is not good'. Doublets of this kind seem to fulfill the metacommunicative function of clarification or disambiguation that involves a native synonym for a foreign word as part of fully traditional discursive constructions in Nahuatl.

There are a number of different mechanisms in play in modern Nahuatl that are best understood within the situation of an increasingly widespread (and transitory) bilingualism. Language innovations spread even to monolingual speakers of a given community through the influence of a growing number of its bilingual members who can have differing degrees of proficiency in the two languages. In general, both in colonial and present times, the concept of linguistic borrowing refers to a diachronic process that began as an individual innovation but was later accepted and diffused in the speech community. Of course every innovation starts with a particular speech act (Haugen 1950: 212). And especially in situations of intense contact, different kinds of borrowings and conversational (intra-sentential) code-switching may become a common mechanism of language change (Field 2002: 21). These spontaneous or 'nonce' borrowings, often instances of code-switching, rarely show phonological and morphological adaptation, contrary to 'established' loanwords (van Hout and Muysken 1994; Muysken 1995; Haspelmath 2009: 40-41). As is well-attested in our dictionary, many loanwords start out as innovations in a particular genre of documents or register of speech and their process of acceptance and diffusion is gradual: some of them are not attested beyond one source, others are found across genres and time periods. In addition, many of the loanwords attested in modern sources reflect a growing proficiency in Spanish. It often surpasses the proficiency in the heritage language among speakers of Nahua communities undergoing shift to the national language. Some of these modern attestations of lexical loans can be clearly identified as examples of spontaneous code-mixing rather than established borrowings that are usually adapted phonologically and/or morphologically. Massive and substitutive borrowing in modern Nahuatl is closely paired with structural and typological changes, revealing an increasing convergence with Spanish. In fact, the large-scale borrowing of Spanish function words accelerates the typological change at a morphosyntactic level. While these trends are clearly visible in our dictionary, it also reveals both microregional trajectories and macroregional trends in language change, extending to the modern variants of Nahuatl. It is through the lexicon that we can much better understand the complexity of longterm interplays and transfers between the Nahuas and Spanish/European, and later Mexican/Latin American language and culture. 


\section{References}

Andrason, Alexander. 2020. Polish Borrowings in Wymysorys. PhD dissertation. Stellenbosh University.

Aguirre Beltrán, Gonzalo. 1967. Regiones de Refugio. Mexico: Instituto Indigenista Interamericano INI.

Aikhenvald, Alexandra. 2006. Reflections on language contact, areal diffusion, and mechanisms of language change. In Sprachbund in the West African Sahel, edited by B. Caron \& Peter Zima, 23-36. Louvain-Paris: Peeters.

Anales de Juan Bautista. 2001. ¿Cómo te confundes? ¿Acaso no somos conquistados? Anales de Juan Bautista. Edited and translated by Luis Reyes García. Mexico: Centro de Investigaciones y Estudios Superiores en Antropología Social, Biblioteca Lorenzo Boturini, Insigne y Nacional Basílica de Guadalupe.

Anderson, Arthur, Frances Berdan \& James Lockhart (trans. and eds.). 1976. Beyond the Codices. The Nahua view of Colonial Mexico, 13-20. Berkeley, Los Angeles, London: University of California Press.

Anderson, Arthur \& Susan Schroeder eds. 1997. Codex Chimalpahin: Society and Politics in Mexico Tenochtitlan, Tlatelolco, Texcoco, Culhuacan, and other Nahua altepetl in central Mexico. The Nahuatl and Spanish annals and accounts collected and recorded by don Domingo de San Antón Muñón Chimalpahin Quauhtlehuanitzin. Civilization of the American Indian series, no. 225, 2 vols. Norman: University of Oklahoma Press

Andrews, J. Richard. 2003. Introduction to Classical Nahuatl. Revised edition. Norman: University of Oklahoma Press.

Berdan, Frances F. 1996. The Tributary Provinces. In Aztec Imperial Strategies, edited by Frances Berdan et al., 115-35. Washington, DC: Dumbarton Oaks Research Library and Collection.

Berdan, Frances F. 2006. The Role of Provincial Elites in the Aztec Empire. In Pre-Columbian States and Empires, edited by Christina Elson and R. Alan Covey, 154-65. Tucson: University of Arizona Press.

Berdan, Frances F. 2007. Continuity and Change in Aztec Culture: From Imperial Lords to Royal Subjects. In Globalization and Change in Fifteen Cultures, edited by George Spindler and Janice Stockard, 1-23. Belmont, CA: Wadsworth.

Berdan, Frances F., and Michael E. Smith. 1996. Imperial Strategies and Core-Periphery Relations. In Aztec Imperial Strategies, edited by Frances Berdan, et al., 209-17. Washington, DC: Dumbarton Oaks Research Library and Collection.

Berdan, Frances F., and Michael E. Smith. 2003. The Aztec Empire. In The Postclassic Mesoamerican World, edited by Michael E. Smith and Frances F. Berdan, 67-72. Salt Lake City: University of Utah Press.

Bergier, Aleksandra \& Justyna Olko. 2016 'Is my Nahuatl coherent?' A comparative analysis of language attitudes among modern Nahua speakers. In Integral strategies for language revitalization, edited by Justyna Olko, Tomasz Wicherkiewicz \& Robert Borges, 297-346. Warsaw: Faculty of "Artes Liberales", University of Warsaw.

Bierhorst, John, ed. \& trans. History and Mythology of the Aztecs. The Codex Chimalpopoca. The Text in Nahuatl with a Glossary and Grammatical Notes. University of Arizona Press, Tucson. Borah, Woodrow. 1983. Justice by Insurance: The General Indian Court of Colonial Mexico and the Legal Aides of the Half-real. University of California Press. 
Burkhart, Louise. 1989. The Slippery Earth: Nahua-Christian Moral Dialogue in SixteenthCentury Mexico. Tucson: University of Arizona Press.

Burkhart, Louise. 2001. Before Guadalupe. The Virigin Mary in Early Colonial Nahuatl Literature. Albany: Institute for Mesoamerican Studies, University at Albany.

Butragueño, Pedro Martín. 2010. El Proceso de Urbanización: Consecuencias Lingüísticas. In Historia sociolingüística de México, edited by Rebeca Barriga Villanueva \& Pedro Martín Butragueño, vol. 2, 997-1093. Mexico: Colegio de Mexico.

Campbell, Lyle. 1987. Syntactic change in Pipil. International Journal of American Linguistics 53(3): 253-280.

Campbell, Lyle. 2006. Areal linguistics: a closer scrutiny. In Linguistic areas: convergence in historical and typological perspective, edited by Yaron Matras, April McMahon \& Nigel Vincent, 1-31. Houndmills, Basingstoke, Hampshire: Palgrave Macmillan.

Campbell, Lyle, Terrence Kaufman \& Thomas Smith-Stark. 1986. Meso-America as a Linguistic Area. Language 62/3. 530-570.

Campbell, Lyle \& Martha Muntzel. 1989. The structural consequences of language death. In Investigating obsolescence: studies in language death, edited by Nancy Dorian, 181-196. Cambridge: Cambridge University Press.

Canger, Una. 1988. Nahuatl Dialectology: A Survey and Some Suggestions. International Journal of American Linguistics 54(1): 28-72.

Canger, Una \& Anne Jensen. 2007. Grammatical borrowing in Nahuatl. In Grammatical Borrowing in Cross-Linguistic Perspective, edited by Yaron Matras \& Jeanette Sakel, 403-418. Berlin: Mouton de Gruyter.

Celestino Solís, Eustaquio, Armando Valencia R., and Constantino Medina Lima. 1985. Actas de Cabildo de Tlaxcala: 1547-1567. Mexico: Archivo General de la Nación; Tlaxcala: Instituto Tlaxcalteca de la Cultura.

Chimalpahin, Don Domingo de San Antón Muñón Quauhtlehuanitzin. 2006. Annals of His Time. Edited and translated by James Lockhart, Susan Schroeder \& Doris Namala. Stanford: Stanford University Press.

Ciudad Real, Antonio de. [1872] 1976. Tratado Curioso y Docto de las Grandezas de la Nueva España. Mexico: Universidad Nacional Autónoma de México.

Cline, Sarah \& Miguel León Portilla. 1986. The Testaments of Culhuacan. Los Angeles: UCLA Latin American Center Publications, University of California.

Chuchiak IV, John. 2012. The Inquisition in New Spain, 1536-1820. A documentary History. Baltimore: The John Hopkins University Press.

Dakin, Karen ed. 1996. Nuestro pesar, nuestra aflicción: Tunetuliniliz, tucucuca, memorias en lengua náhuatl enviadas a Felipe II por indígenas del Valle de Guatemala hacia 1572. Mexico City, Antigua, Guatemala and South Woodstock, VT: Universidad Nacional Autónoma de México, Centro de Investigaciones Regionales de Mesoamérica, Plumsock Mesoamerican Studies.

Dakin, Karen. 2010. Lenguas francas y lenguas locales en la época prehispánica. In Historia sociolingüística de México, edited by Rebeca Barriga Villanueva and Pedro Martín Butragueño, Vol 1, 161-183. Mexico: Colegio de Mexico.

Dakin Karen \& Soeren Wichman. 2000. Cacao and Chocolate. A Uto-Aztecan perspective, Ancient Mesoamerica 11: 55-75.

Doctrina Cristiana. 1550. Doctrina cristiana en lengua española y mexicana hecha por los religiosos de la orden de Santo Domingo. Mexico City: Juan Pablos. 
Field, Fredric. 2003. Linguistic Borrowing in Bilingual Contexts. Amsterdam: John Benjamins.

Flores Farfán, José Antonio. 1999. Cuatreros Somos y Toindioma Hablamos. Contactos y Conflictos entre el Náhuatl y el Español en el Sur de México. Tlalpan, D.F.: Centro de Investigaciones y Estudios Superiores en Antropología Social.

Flores Farfán, José Antonio. 2000. Transferencias náhuatl-español en el Balsas. Reflexiones sobre el desplazamiento y la resistencia lingüística en el náhuatl moderno. Amerindia 25: 87-106.

Flores Farfán. José Antonio. 2003. Nahuatl purism: Between language innovation, maintenance and shift. In: Purism in the age of globalization, edited by J. Brincat et al, 281-313. Bochum: Universitätsverlag Dr. N. Brockmeyer.

Flores Farfán, José Antonio. 2008. The Hispanization of modern Nahuatl varieties. In Hispanisation: The impact of Spanish on the lexicon and grammar of the indigenous languages of Austronesia and the Americas, edited by Thomas Stolz, Dik Bakker \& Rosa Salas Palomo, 27-48. Berlin \& New York: Mouton de Gruyter.

González Luna, Ana María. 2012. La política lingüistica en México entre Independencia y Revolución (1810-1910). Actas del Congreso de la Asociación Internacional de Hispanistas, 91-101. Rome: Bagatto Libri.

Granicka, Katarzyna. 2018. Confronting Cultural Difference. The 1548 Doctrina as a vehicle for contact-induced change in Nahua language and culture. Doctoral dissertation. Warsaw: Faculty of "Artes Liberales", University of Warsaw.

Greenleaf, Richard E. 1961. Zumárraga and the Mexican Inquisition, 1536-1543. Washington DC: Academy of American Franciscan History.

Greenleaf, Richard E. 1994. Persistence of Native Values: The Inquisition and the Indians of Colonial Mexico. The Americas 50(3): 351-76.

Hammarström, Harald, Robert Forkel, Martin Haspelmath \& Sebastian Bank. 2016. Glottolog 2.7. Jena: Max Planck Institute for the Science of Human History.

Haspelmath, Martin. 2009. Lexical borrowing: Concepts and Issues. In: Loanwords in the World's Languages. A Comparative Handbook, eds. Martin Haspelmath \& Uri Tadmor, pp. 35-54. Walter de Gruyter

Haugen, Einar. 1950. The Analysis of Linguistic Borrowing. Language 26: 210-231.

Heath, Shirley Brice. 1972. Telling Tongues: Language Policy in Mexico, Colony to Nation. New York: Teachers College Press.

Heine, Bernd \& Tania Kuteva. 2005. Language Contact and Grammatical Change. Cambridge: Cambridge University Press.

Hill, Jane \& Kenneth C. Hill. 1986. Speaking Mexicano: Dynamics of syncretic language in Central Mexico. Tucson: University of Arizona Press.

Horn, Rebecca. 1997. Postconquest Coyoacan: Nahua-Spanish Relations in Central Mexico, 1519-1650. Stanford, CA: Stanford University Press

Hout, Roeland van and Pieter Muysken. 1994. Modeling lexical borrowability. Language Variation and Change, 6: 39-62.

INEGI (Instituto Nacional de Estadística, Geografía e Informática). 2010. Censo de población y vivienda 2010. Características culturales de la población, Población hablante de lengua indigena de 5 y más años por principales lenguas. Available online at: htp://www3.inegi. org.mx/sistemas/temas/default.aspx?s=est\&c=19004

Karttunen, Frances. 1992. An Analytical Dictionary of Nahuatl. Norman: University of Oklahoma Press.

Karttunen, Frances E. \& James Lockhart. 1976. Nahuatl in the middle years: Language contact phenomena in texts of the colonial period. Berkeley: University of California Press. 
Karttunen, Frances E. \& James Lockhart eds. 1987. The Art of Nahuatl Speech. The Bancroft Dialogues. Latin American Studies, Vol. 65. Los Angeles: UCLA.

Kaufman, Terrence. 2001. The history of the Nawa language group from the earliest times to the sixteenth century: some initial results". Project for the Documentation of the Languages of Mesoamerica.

Kaufman, Terrence \& John Justeson. 2009. Historical Linguistics and Pre-Columbian Mesoamerica. Ancient Mesoamerica, 20(2): 221-231.

Kouwenberg, Silvia. 2001. Convergence and explanations in creole genesis. In Creolization and Contact, edited by Norval Smith and Tonjes Veenstra, 219-247. Amsterdam: John Benjamins.

Lastra, de Suárez Yolanda. 1986. Las Áreas Dialectales del Náhuatl Moderno Serie Antropológica no. 62. Mexico: Instituto de Investigaciones Antropológicas Lingüística.

Lastra, de Suárez Yolanda. 2010. Diversidad lingüística: variación dialectal actual. In Historia sociolingüística de México, edited by Rebeca Barriga Villanueva \& Pedro Martín Butragueño, vol. 2, 841-879. Mexico: Colegio de Mexico.

Launey, Michel. 2004. The features of omnipredicativity in Classical Nahuatl. STUF 57(1): 49-69.

Launey, Michel. 2011. An introduction to Classical Nahuatl. Cambridge: Cambridge University Press.

Lockhart, James. 1991. Nahuas and Spaniards. Postconquest Central Mexican history and philology. Stanford and Los Angeles: Stanford University Press, Latin American Center Publications, University of California.

Lockhart, James. 1992. The Nahuas after the conquest. A social and cultural history of the Indians of Central Mexico, sixteenth through eighteenth centuries. Stanford: Stanford University Press.

Lockhart, James. 2001. Nahuatl as written: Lessons in older written Nahuatl with copious examples and texts. Stanford: Stanford University Press.

Lockhart, James, Frances Berdan \& Arthur J.O. Anderson, eds. 1986. The Tlaxcalan Actas. A Compendium of the Records of the Cabildo of Tlaxcala (1545-1627). Salt Lake City: University of Utah Press.

Macri, Martha J., \& Matthew Looper G. 2003. Nahua in ancient Mesoamerica. Ancient Mesoamerica 14: 285-297.

Martínez Casas, Regina. 2010 De la eesistencia al desplazamiento de las lenguas indígenas en situaciones de migración. In Historia sociolingüística de México, edited by Rebeca Barriga Villanueva \& Pedro Martín Butragueño, vol. 3, 1409-1455. Mexico: Colegio de Mexico.

Matras, Yaron. 2007. The borrowability of structural categories. In Grammatical Borrowing in Cross-Linguistic Perspective, edited by Yaron Matras \& Jeanette Sakel, 31-73. Berlin: Mouton de Gruyter.

Matras, Yaron. 2009. Language Contact. Cambridge: Cambridge University Press.

Matras, Yaron \& Jeanette Sakel, eds. 2007. Grammatical Borrowing in Cross-Linguistic Perspective. Berlin: Mouton de Gruyter.

Melton-Villanueva, Miriam. 2012. The Nahuas at Independence: Indigenous Communities of the Metepec Area (Toluca Valley) in the First Decades of the Nineteenth Century. A dissertation submitted in partial satisfaction of the requirements for the degree Doctor of Philosophy in History. Los Angeles: University of California.

Melton-Villanueva, Miriam. 2016. The Nahuas at Independence. The Nahua Culture-Makers at Central Mexico, 1799-1932. Tucson: University of Arizona Press. 
Molina, Fray Alonso de. 1984 [1569]. Confesionario mayor en lengua mexicana y castellana (1569). Mexico City: Universidad Nacional Autonóma de México.

Molina, fray Alonso de. [1571] 1992. Vocabulario en lengua castellana y mexicana y mexicana castellana. Mexico: Editorial Porrúa.

Muysken, Pieter C. 2000. Bilingual Speech: A Typology of Code-Mixing. Cambridge: Cambridge University Press.

Muysken, Pieter C. 2008. Introduction: conceptual and methodological issues in areal linguistics. In From Linguistic Areas to Areal Linguistics, edited by Peter C. Muysken, 1-24. Amsterdam: John Benjamins.

Myers-Scotton, Carol. 2002. Contact Linguistics. Bilingual Encounters and Grammatical Outcomes. Oxford: Oxford University Press.

Nava Nava, Refugio. 2016. La socialización infantil bilingüe en San Isidro Buensuceso, Tlaxcala, México. Revista Española de Antropología Americana 46: 29-47.

Nutini, Hugo H. \& Barry L. Isaac. 1974. Los pueblos de habla náhuatl de la región de Tlaxcala y Puebla. Mexico: Instituto Nacional Indigenista.

Nutini, Hugo H. \& Barry L. Isaac. 2009. Social stratification in Central Mexico. University of Texas Press.

Olko, Justyna. 2015. Language encounters: toward a better comprehension of contact-induced lexical change in colonial Nahuatl. Politeja 38: 35-52.

Olko, Justyna. 2018. Unbalanced Language Contact and the Struggle for Survival: Bridging Diachronic and Synchronic Perspectives on Nahuatl. European Review 26(1): 207-228.

Olko, Justyna \& Agnieszka Brylak, 2018. Defending local autonomy and facing cultural trauma. A Nahua order against idolatry, Tlaxcala 1543. Hispanic American Historical Review 98(4): 573-604.

Olko, Justyna \& John Sullivan. 2014. Toward a Comprehensive Model for Nahuatl Language Research and Revitalization. Proceedings of the Fortieth Annual Meeting of the Berkeley Linguistics Society 40: 369-397.

Olko, Justyna, Robert Borges \& John Sullivan. 2018. Convergence as the driving force of typological change in Nahuatl. Language Typology and Universals 71(3): 467-507.

Olko, Justyna, John Sullivan and Jan Szemiński (eds.). 2018. Dialogue with Europe, Dialogue with the Past. Colonial Nahua and Quechua Elites in Their Own Words. University of Colorado Press, Boulder.

Olko, Justyna \& Jan Szemiński. 2018. Nahua and Quechua Elites of the Colonial Period: Continuity and Change in a Cross-Cultural Context. In Dialogue with Europe, Dialogue with the Past. Colonial Nahua and Quechua Elites in Their Own Words, edited by Justyna Olko, John Sullivan \& Jan Szemiński. University of Colorado Press, Boulder.

Parodi, Claudia. 2010 Tensión lingüística en la colonia: diglosia y bilingüismo. In Historia sociolingüística de México, edited by Rebeca Barriga Villanueva \& Pedro Martín Butragueño, vol. 2, 287-345. Mexico: Colegio de Mexico.

Pellicer, Dora. 2010. Lenguas, relaciones de poder y derechos lingüísticos. In Historia sociolingüística de México, edited by Rebeca Barriga Villanueva \& Pedro Martín Butragueño, vol. 2, 605-658. Mexico: Colegio de Mexico.

Phelan, John Leddy. 1970. The millennial kingdom of the Franciscans in the New World. Berkeley \& Los Angeles: University of California Press.

Pizzigoni, Caterina. 2007. Testaments of Toluca. Stanford: Stanford University Press. 
Rojas Rabiela, Teresa, Elsa Leticia Rea López, and Constantino Medina Luna eds. 1999-2002. Vidas y bienes olvidados: Testamentos indígenas novohispanos, 4 vols. Mexico: CIESAS.

Sahagún, Fray Bernardino de. 1950-82. Florentine Codex: General History of the Things of New Spain, edited by Arthur J. O. Anderson and Charles Dibble. 12 vols. Santa Fe, NM: School of American Research.

Sahagún, Fray Bernardino de. 1997. Primeros Memoriales, edited by Thelma D. Sullivan. Norman: University of Oklahoma Press.

Sakel, Jeanette. 2007. Types of loan: Matter and pattern. In Grammatical Borrowing in Cross-Linguistic Perspective, edited by Yaron Matras, \& Jeanette Sakel, 15-30. Berlin: Mouton de Gruyter.

Sandstrom, Alan R. 1991. Corn Is Our Blood: Culture and Ethnic Identity in a Contemporary Aztec Indian Village. Norman: University of Oklahoma Press.

Sell, Barry D., Louise M. Burkhart, Gregory Spira, \& Miguel Leon-Portilla eds. 2004. Nahuatl Theater Volume I: Death and Life in Colonial Nahua Mexico. Norman: University of Oklahoma Press.

Sell, Barry, Louise Burkhart \& Stafford Poole eds. 2006. Nahuatl Theater, Volume 2 Our Lady of Guadalupe. University of Oklahoma Press: Norman.

Smith, Michael E. 2005. Life in the Provinces of the Aztec Empire. Scientific American 90-7.

Smith, Michael E. 2008. Aztec City-State Capitals. Gainesville, FL: University Press of Florida.

Sullivan, John. 2003. Ytechcopa timoteilhuia yn tobicario (Acusamos a nuestro vicario): Pleito entre los naturales de Jalostotitlán y su sacerdote, 1618. Zapopan, Jalisco: El Colegio de Jalisco.

Sullivan, John, Eduardo de la Cruz Cruz, Abelardo de la Cruz de la Cruz, Delfina de la Cruz de la Cruz, Victoriano de la Cruz Cruz, Sabina Cruz de la Cruz, Ofelia Cruz Morales, Catalina Cruz de la Cruz and Manuel de la Cruz Cruz (eds.). 2016. Tlahtolxitlauhcayotl: Chicontepec, Veracruz. Totlahtol Series. Series editors, Justyna Olko and John Sullivan. Warsaw: IDIEZ/ University of Warsaw.

Suárez Jorge a. 1983. The Mesoamerican Indian languages. Cambridge: Cambridge University Press.

Swadesh, Morris. 1971. The Origin and Diversification of Language. Edited post mortem by Joel Sherzer. Chicago: Aldine.

Tadmor, Uri. 2009. Loanwords in the world's languages: Findings and results. In Loanwords in the World's Languages. A Comparative Handbook, edited by Martin Haspelmath \& Uri Tadmor, 55-75. Berlin: Walter de Gruyter.

Thomason, Sarah G. 2001. Langauge Contact. Edinburgh: Edinburgh University Press.

Thomason, Sarah G., 2014. Contact-induced language change and typological congruence. In Congruence in Contact-Induced Language Change. Language Families, Typological Resemblance, and Perceived Similarity, edited by Juliane Besters-Dilger et al., 201-218. Berlin: Mouton de Gruyter.

Thomason, Sarah G. \& Terrence Kaufmann. 1988. Language contact, creolization, and genetic linguistics. Berkely: University of California Press.

Townsend, Camilla. 2010. Here in this year: Seventeenth-century Nahuatl annals of the TlaxcalaPuebla valley. Stanford: Stanford University Press.

Van Hout, R. \& P. Muysken. 1994. Modeling lexical borrowability. In Language Variation and Change 6(1): 39-62. 
Villavicencio Zarza, Frida. 2010. Entre una realidad plurilingüe y un anhelo de nación. Apuntespara un estudio sociolingüístico del siglo XIX. In Historia sociolingüística de México, edited by Rebeca Barriga Villanueva \& Pedro Martín Butragueño, vol. 2, 713-793. Mexico: Colegio de Mexico.

Villavicencio Zarza, Frida. 2013. Lenguas indigenas en el Mexico decimonónico. Ecos, pregones y contrapuntos. Mexico: CIESAS.

Weinreich, Uriel. 1953. Languages in Contact. The Hague: Mouton.

Yakpo, Kofi, Margot van den Berg \& Robert Borges. 2015. On the Linguistic Consequences of Language Contact in Suriname: The Case of Convergence. In In and out of Suriname: langauge, mobility and identity, edited by Eithne B. Carlin, Isabelle Léglise, Bettina Migge \& Paul Tjon Sie Fat, 164-195. Leiden: KITLV Press.

Yannanakis, Yanna. 2012. Introduction: How Did They Talk to One Another? Language Use and Communication in Multilingual New Spain. Ethnohistory 59(4): 667-674.

Zapata y Mendoza, don Juan Buenaventura. 1995. Historia cronológica de la Noble Ciudad de Tlaxcala. Edited and translated by Luis Reyes García \& Andrea Martinez Baracs. Tlaxcala and Mexico: Universidad Nacional Autónoma de Tlaxcala and Centro de Investigaciones y Estudios Superiores en Antropología Social.

Zimmerman, Klaus. 2010. Diglosia y otros usos diferenciados de lenguas y variedades en el México del siglo XX: entre el desplazamiento y la revitalización de las lenguas indomexicanas. In Historia sociolingüística de México, edited by Rebeca Barriga Villanueva \& Pedro Martín Butragueño, vol. 2, 881-955. Mexico: Colegio de Mexico. 